METABOLIC STUDIES IN PARALYTIC ACUTE ANTERIOR POLIOMYELITIS ${ }^{1}$

I. ALTERATIONS IN NITROGEN AND CREATINE METABOLISM.

II. ALTERATIONS IN CALCIUM AND PHOSPHORUS METABOLISM.

III. METABOLIC AND CIRCULATORY EFFECTS OF THE SLOWLY OSCILLATING BED.

IV. EFFECTS OF TESTOSTERONE PROPIONATE AND ESTRADIOL BENZOATE ON CALCIUM, PHOSPHORUS, NITROGEN, CREATINE AND ELECTROLYTE METABOLISM.

APPENDIX A: TABLES OF METABOLIC BALANCE DATA.

APPENDIX B: CASE SUMMARIES OF ELEVEN PATIENTS WITH PARALYTIC ACUTE ANTERIOR POLIOMYELITIS.

By G. DONALD WHEDON ${ }^{2}$ AND EPHRAIM SHORR $\dagger$

WITH THE TECHNICAL ASSISTANCE

of VINCENT TOSCANI AND ESTELLE STEVENS

(From the Russell Sage Institute of Pathology, the Department of Medicine, Cornell University Medical College, and the New York Hospital, New York, N. Y.)

1 Aided by a grant from the National Foundation for Infantile Paralysis.

2 Present Address: National Institute of Arthritis and Metabolic Diseases, National Institutes of Health, Bethesda, Maryland.

$\dagger$ Died, January 6, 1956. 


\title{
METABOLIC STUDIES IN PARALYTIC ACUTE ANTERIOR POLIOMYELITIS. I. ALTERATIONS IN NITROGEN AND CREATINE METABOLISM ${ }^{1}$
}

\author{
By G. DONALD WHEDON ${ }^{2}$ AND EPHRAIM SHORR $\dagger$ \\ WITH THE TECHNICAL ASSISTANCE \\ of VINCENT TOSCANI AND ESTELLE STEVENS

\begin{abstract}
(From the Russell Sage Institute of Pathology, the Department of Medicine, Cornell University
\end{abstract} \\ Medical College, and the New York Hospital, New York, N. Y.)
}

(Submitted for publication July 27, 1955; accepted November 26, 1956)

For hundreds of years acute anterior poliomyelitis has been regarded as involving exclusively the motor nerves and the muscles served by them. Prolonged after-effects on muscles have called attention to chronic features of this acute infectious disease, but serious and persistent involvement of systems other than the muscular, such as the skeletal, urinary or respiratory, has been barely recognized.

The studies to be reported show that infection with the virus of poliomyelitis, while undoubtedly exercising a primary effect on motor and other nerve cells of the spinal cord and brain, may have pronounced secondary effects upon many systems and particularly upon muscle and skeletal metabolism.

The major objective of these studies was to outline the metabolic and physiological features of the natural course of paralytic acute anterior poliomyelitis during acute, convalescent and chronic phases. The most important changes with respect to nitrogen, creatine, calcium and phosphorus are presented in the first two papers of this series of four ; disturbances in the metabolism of electrolytes are given in the fourth paper. Since patients with this disease could not be studied untreated, the natural course is defined as evolution of the illness during treatment with standard modern methods of physical therapy. Using these observations of the natural course as a base-line, assessment was made of metabolic and circulatory influences of the slowly oscillating (Sanders) bed (1), described in the third paper, and of the effects of

\footnotetext{
1 Aided by a grant from the National Foundation for Infantile Paralysis.

2 Present Address: National Institute of Arthritis and Metabolic Diseases, National Institutes of Health, Bethesda, Maryland.

† Died, January 6, 1956.
}

androgenic and estrogenic hormones, reported in the fourth paper.

The investigation was initiated as a result of previous observations of the effects of immobilization (2) in four normal young male subjects which had revealed significant losses of nitrogen, calcium and other minerals, disturbance in creatine metabolism and in peripheral circulation, as well as losses of muscle mass and strength. In view of the substantial derangements resulting from immobilization per se in healthy individuals, it seemed desirable to ascertain to what extent metabolic alterations might occur in a disease such as acute anterior poliomyelitis when associated with prolonged and extreme immobilization.

\section{PREVIOUS OBSERVATIONS OF METABOLISM IN POLIOMYELITIS}

Few observations have been made revealing abnormal metabolism in poliomyelitis. Creatinuria accompanying the chronic stage of acute anterior poliomyelitis was first described by Levene and Kristeller (3) in 1909. Other observers have also noted diminished urinary creatinine (4-10) and diminished retention of exogenous creatine (6-10) during the convalescent and chronic phases. A few measurements of creatinuria during the early weeks of the disease (11-13) have been made but revealed no consistent pattern of excretion. In these latter studies, the value of the creatine determinations is suspect, because extreme variations in 24-hour creatinine excretion in individual patients indicated incomplete urine collections.

The relationship of creatinuria to virus infection has been investigated in animals by Gifford and Dalldorf (14), who detected creatinuria in suckling mice experimentally infected with Coxsackie virus.

Whether correlation can be shown in patients between the level of creatinuria and extent of muscle paralysis is unsettled. In comparable observations, Wang (11) after study of eight cases and Brøchner-Mortenson (12) from twelve cases came to opposite conclusions.

Various isolated studies suggesting abnormal nitrogen metabolism in poliomyelitis have been carried out from 


\section{DISEASE PHASES AND DURATION OF METABOLIC STUDIES}

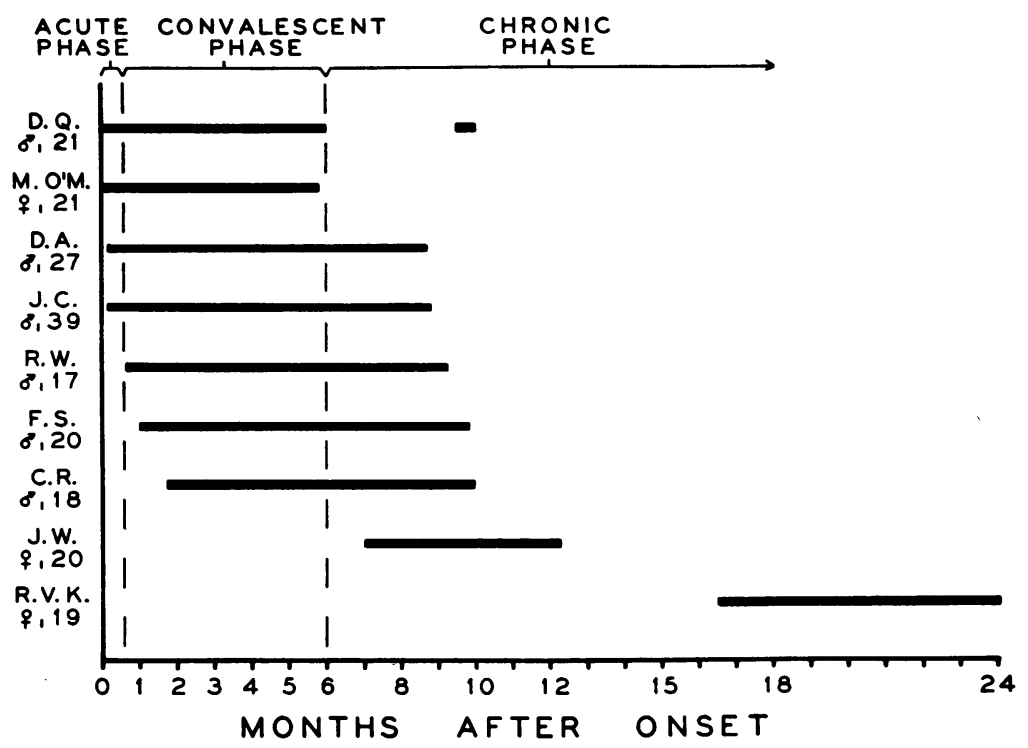

Fig. 1. The Phases of Acute Anterior Poliomyelitis during Which Metabolic Studies Were Carried Out in Nine Patients, and the Duration of These Studies in Each Case

which few conclusions can be drawn. Nitrogen balance has been carefully though briefly measured by only one investigator, Bürger (4) in 1919, who found a small negative balance lasting a few days in one of two patients studied several weeks after onset of illness. Data on urinary nitrogen excretion have been presented by Bower, Morgan, and Chaney (15) on 17 patients observed for periods up to three months after onset. In these patients, nearly all of whom required the aid of a respirator, large amounts of nitrogen were excreted in association with a fall in serum albumin and rise in serum globulin. Bower, Eaton, Chudnoff, Affeldt, and Chaney (16) had previously reported similar alterations in serum albumin and globulin in severely involved patients during the acute phase of poliomyelitis. Routh and Paul (17) confirmed these findings by electrophoretic analysis, but Steigman, Brodsky, and Stephens (18) in 125 patients could find no decline in serum albumin during the acute phase. This was the state of the literature at the time these papers were being written; several reports have been included (12-18) which were published while we were engaged in these studies.

\section{GENERAL PLAN}

Eleven patients were studied, all with marked and wide-spread muscle weakness and paralysis. Nine were studied on the Metabolism Ward of the Russell Sage Institute of Pathology and the New York Hospital for periods ranging from five to nine months. Figure 1 indicates for each of these nine patients the duration of study and phase of disease during which study was carried out.
In four of the nine, investigation was begun early in the acute phase of the disease. Two patients were observed for brief periods on the Infectious Disease Ward only, under less rigidly controllable conditions, and are reported only in the third paper, on the effects of the oscillating bed.

Of the nine patients reported in this paper, one received no treatment other than generally accepted standard medical and physical therapy (to be described below) throughout the six months he was observed, beginning on the day of onset of paralysis. The other patients also received conventional therapy but in addition, interrupting observation of the natural course of their disease, were either placed on a slowly oscillating Sanders bed or given androgens or estrogens for a few weeks at a time on one or more occasions. The data obtained during and for two to four weeks after the intervals in which these special procedures were employed have been omitted from the present report in order to provide as uncomplicated as possible a picture of the natural course, and have been reserved for subsequent papers in this series. Exclusion of these data is responsible for the interrupted nature of a number of the graphs in this paper. Consecutive metabolic data, including periods on and following special procedures, are given in tables in Appendix A.

The patients ranged in age from 17 to 39 years. Three (M.O'M., J.W., and R.V.K.) of the nine were females. Muscle paresis was extensive in all, seven of the nine having all four limbs involved; in two (D.Q. and J. C.), the upper extremities were unaffected. Two (C.R. and R.V.K.) required tank respirators for a few weeks prior 
to entering this study. Extent of muscular paralysis was estimated from reduction in urinary creatinine and ranged from 30 to 80 per cent, with most patients showing a 40 per cent to 60 per cent loss of muscle mass. Detailed case summaries are given in Appendix B.

\section{PROCEDURE}

The four patients whose studies were initiated during the acute phase were first observed on the Infectious Disease Ward. Daily 24-hour urine collections were begun on the third day after onset of illness with D.Q., on the fourth day after onset with M.O'M., and on the sixth day with D.A. and J. C. Onset of illness was taken as the first day on which the temperature was elevated to $100^{\circ} \mathrm{F}$ or above; this was usually two or more days prior to hospital admission. In the case of D.Q., we began urine collections on the morning of the day muscle weakness was first noted; in M.O'M., D. A., and J. C. urine collections were begun on the first, second and fourth days, respectively, following onset of muscle weakness. On the Infectious Disease Ward, record was made of daily fluid and food intake, and the patients were weighed at weekly intervals.

The four patients were transferred to the Metabolism Ward 14 to 21 days after onset of illness, 8 to 10 days after the temperature had returned to normal levels. As soon as each patient could eat a constant diet, collection and analysis of stool were begun, in addition to those of urine, so that balances could be calculated. Rigid precautions against contagion were observed by the nursing staff in handling stool specimens. Drying the stools at $100^{\circ} \mathrm{C}$ for 24 to 48 hours over a steam bath was considered adequate to inactivate the virus prior to chemical analysis.

The five remaining patients in the group had been cared for in other hospitals during the acute phase of their illness and, when transferred to the New York Hospital, were admitted directly to the Metabolism Ward. Metabolic study of three of these patients was begun during the convalescent phase of their disease, the observation of R.W. beginning on the 19th day after onset of illness, that of F.S. on the 30th day and that of C.R. on the 49th day. Studies on J.W. and R.V.K. were begun during the 7 th and 17 th months, respectively, after onset of illness.

\section{PATIENTS' CARE AND THERAPY}

Management of patients during the acute phase involved not only care of muscles but attention to comfort, respiration, sphincter control and fluid balance. Urinary infections in two patients following catheterization responded promptly to brief courses of sulfadiazine.

Hot pack therapy to the entire back and extremities was instituted upon admission and was administered for 3 to 8 hours daily for two and one-half months; in one patient who had prolonged muscle stiffness, C.R., hot packs were continued for four and one-half months. In some instances packs were supplemented with hot tubs. Passive motion of extremities and muscle stretching twice daily were begun within the first ten days, shortly after temperature had returned to normal. Muscle reeducation was generally added during the third week. Initiated in bed, this procedure was later carried out in a therapeutic pool at $92^{\circ} \mathrm{F}$ and still later in a gymnasium. Therapy in the pool was started two to two and one-half months after onset of illness or approximately at the time hot packs were discontinued, and was gradually lengthened from 15 minutes to 45 minutes once or twice daily.

Time of mobilization to wheel-chair and, when possible, to standing and walking varied widely. Patients D.Q., M.O'M., D.A., J.C., and R.W. began sitting in a chair two and one-half to four months and walking three and one-half to seven months after onset. F.S. and C.R., with more severe muscle involvement, began sitting near the end of their metabolic study, approximately 9 months after onset. J.W. and R.V.K., who were studied only during the chronic phase, sat up for one and one-half hours daily throughout the study. Further details are given in the patients' case summaries, Appendix B.

\section{DIETS}

During the acute phase, appetite was poor and food intake low for a few days, but both were variably restored within the first two weeks. During this phase food intake was recorded and calculated. Only the intake of milk was regulated, at three glasses daily, to limit calcium intake to 1.0 gram. Fluid intake was maintained at more than $2000 \mathrm{ml}$. daily.

When the patients were transferred or admitted directly to the Metabolism Ward, they began to receive constant dietary intakes (Table I). For each diet there were three or four daily menus rotated in succession which were virtually identical in caloric value and protein and mineral content; one menu was creatine-creatinine free (containing no meat or fish). When necessitated by a markedly altered appetite demand or an undesirable trend in body weight, a change was made in the diet to a new constant caloric level without changing protein and mineral intake. Protein intake was set at levels of 1.0 to 1.4 grams per kilogram of pre-illness body weight. Mineral constituents were also set at moderate but adequate levels. Sodium intake was kept constant at 4.0 grams (sodium chloride, $10.25 \mathrm{gm}$.) per day in five studies by giving the patients weghed amounts of extra sodium chloride to be sprinkled over the food; the amounts added depended on the sodium values of the diets as determined by analysis.

Calculated values for caloric and mineral content of foods were obtained from standard tables (19-21). Sodium and potassium values were obtained from Mead Johnson reports $(22,23)$.

Twenty-four analyses of diets were made during the study, at least one of each menu used at each caloric level, amounting to a little more than 1 per cent of the approximately 1900 calculated and weighed diets served during the entire investigation. Average percentage of calculated values found by analysis was 103.1 per cent for nitrogen, 101.2 per cent for calcium, 95.5 per cent for 
TABLE I

Summary of calculated constant dietary intakes, convalescent and chronic phases of paralytic acute anterior poliomyelitis

\begin{tabular}{|c|c|c|c|c|c|c|c|c|c|c|c|}
\hline Patient & $\begin{array}{l}\text { Number of } \\
\text { six-day } \\
\text { periods } \\
\text { on diet }\end{array}$ & $\begin{array}{l}\text { Interval } \\
\text { on diet, } \\
\text { days after } \\
\text { onset }\end{array}$ & Calories & $\mathrm{CHO}$ & Fat & Protein & $\mathbf{N}$ & $\mathrm{Ca}$ & $P$ & $\mathbf{K}$ & $\mathrm{Na}$ \\
\hline D. Q. & $\begin{array}{r}4 \\
20 \\
2\end{array}$ & $\begin{array}{c}32-56 \\
57-176 \\
282-297\end{array}$ & $\begin{array}{l}2,020 \\
2,408 \\
2,408\end{array}$ & $\begin{array}{l}g m . \\
199 \\
297 \\
297\end{array}$ & $\begin{array}{l}g m . \\
100 \\
100 \\
100\end{array}$ & $\begin{array}{l}g m . \\
80 \\
80 \\
80\end{array}$ & $\begin{array}{c}g m . \\
12.82 \\
12.82 \\
12.82\end{array}$ & $\begin{array}{c}g m . \\
0.920 \\
0.921 \\
0.921\end{array}$ & $\begin{array}{c}g m . \\
1.416 \\
1.462 \\
1.462\end{array}$ & $\begin{array}{l}g m . \\
2.80 \\
3.01 \\
3.01\end{array}$ & $\begin{array}{l}g m . \\
4.00\end{array}$ \\
\hline M. O'M. & 24 & $25-173$ & 1,801 & 200 & 80 & 70 & 11.28 & 0.921 & 1.354 & 2.65 & \\
\hline D. A. & $\begin{array}{l}21 \\
19\end{array}$ & $\begin{array}{r}17-146 \\
147-261\end{array}$ & $\begin{array}{l}2,800 \\
2,000\end{array}$ & $\begin{array}{l}353 \\
209\end{array}$ & $\begin{array}{r}114 \\
89\end{array}$ & $\begin{array}{l}90 \\
90\end{array}$ & $\begin{array}{l}14.37 \\
14.42\end{array}$ & $\begin{array}{l}0.920 \\
0.920\end{array}$ & $\begin{array}{l}1.638 \\
1.545\end{array}$ & $\begin{array}{l}3.50 \\
2.88\end{array}$ & $\begin{array}{l}4.00 \\
4.00\end{array}$ \\
\hline J. C. & $\begin{array}{l}16 \\
23\end{array}$ & $\begin{array}{r}23-123 \\
124-262\end{array}$ & $\begin{array}{l}2,397 \\
2,797\end{array}$ & $\begin{array}{l}274 \\
349\end{array}$ & $\begin{array}{l}109 \\
120\end{array}$ & $\begin{array}{l}80 \\
80\end{array}$ & $\begin{array}{l}12.78 \\
12.80\end{array}$ & $\begin{array}{l}0.919 \\
0.921\end{array}$ & $\begin{array}{l}1.434 \\
1.424\end{array}$ & $\begin{array}{l}3.07 \\
4.14\end{array}$ & \\
\hline R. W. & $\begin{array}{l}12 \\
13 \\
18\end{array}$ & $\begin{array}{c}22-93 \\
94-171 \\
172-280\end{array}$ & $\begin{array}{l}2,002 \\
2,398 \\
2,801\end{array}$ & $\begin{array}{l}202 \\
274 \\
333\end{array}$ & $\begin{array}{r}97 \\
109 \\
128\end{array}$ & $\begin{array}{l}80 \\
80 \\
80\end{array}$ & $\begin{array}{l}12.80 \\
12.80 \\
12.78\end{array}$ & $\begin{array}{l}0.920 \\
0.920 \\
0.920\end{array}$ & $\begin{array}{l}1.352 \\
1.434 \\
1.453\end{array}$ & $\begin{array}{l}2.78 \\
3.08 \\
3.54\end{array}$ & $\begin{array}{l}4.00 \\
4.00 \\
4.00\end{array}$ \\
\hline F.S. & 43 & $31-294$ & 2,798 & 351 & 115 & 90 & 14.40 & 0.922 & 1.659 & 4.09 & 4.00 \\
\hline C. R. & 40 & $50-300$ & 1,997 & 199 & 98 & 80 & 12.82 & 0.921 & 1.379 & 2.66 & 4.00 \\
\hline J. W. & 23 & $212-369$ & 1,803 & 222 & 66 & 80 & 12.84 & 1.005 & 1.709 & 2.75 & \\
\hline R. V. K. & $\begin{array}{l}25 \\
13\end{array}$ & $\begin{array}{l}503-656 \\
657-735\end{array}$ & $\begin{array}{l}1,595 \\
1,938\end{array}$ & $\begin{array}{l}208 \\
233\end{array}$ & $\begin{array}{l}59 \\
78\end{array}$ & $\begin{array}{l}58 \\
76\end{array}$ & $\begin{array}{r}9.36 \\
12.16\end{array}$ & $\begin{array}{l}0.888 \\
1.478\end{array}$ & $\begin{array}{l}1.329 \\
1.794\end{array}$ & $\begin{array}{l}2.81 \\
3.52\end{array}$ & \\
\hline
\end{tabular}

phosphorus, 98.7 per cent for sodium and 100.4 per cent for potassium. However, appreciable day to day variation, amounting to \pm 6 to 9 per cent, is indicated by the standard deviations of analyzed from calculated values ( $\pm 0.82 \mathrm{gm}$. for nitrogen, $\pm 0.061 \mathrm{gm}$. for calcium, \pm 0.131 gm. for phosphorus, $\pm 0.163 \mathrm{gm}$. for sodium and \pm 0.302 gm. for potassium).

\section{METHODS}

Ward routine and methods employed on the Metabolism Ward have been previously reported (24). Procedures are similar to those of Sampson, Sprague, and Wollaeger (25) and Reifenstein, Albright, and Wells (26).

Urinary nitrogen, creatine, creatinine, $\mathrm{pH}$ and specific gravity were determined on 24-hour urinary specimens. Three-day pooled specimens made up from 10 per cent aliquots of the 24-hour collections were used for the analyses for urinary glycocyamine, calcium, phosphorus, citric acid, and sulphur. Analyses for 17-ketosteroids were carried out during the early weeks on three-day and later on six-day pooled specimens. Pooled specimens were preserved for many months for check analyses by the addition of $2 \mathrm{ml}$. conc. $\mathrm{HCl}$ per $100 \mathrm{ml}$. of specimen. Sodium, potassium, and chloride analyses were performed on unacidified refrigerated three-day pooled specimens.

Balance studies were carried out in six-day periods. Fecal nitrogen, calcium, phosphorus, sodium, and potassium were determined by chemical analysis. Methods of stool marking, collection and preparation for analysis have been reported elsewhere (27). Diets were analyzed in toto (rather than by separate analyses of individual foods), a one-half aliquot of a day's menu being weighed out, mixed together, ground and then prepared for analysis in the same manner as in the preparation of a stool for analysis.

Nitrogen in urine and stool was analyzed by a modification of the Kjeldahl method (28). Urinary total sulphate reported as sulphur was determined by the method of Folin (29), urinary creatine by the Benedict modification of Folin's method (30) (which converts creatine to creatinine) and creatinine by the method of Folin (31). Urinary 17-ketosteroids were determined by a modification of the method of Callow, Callow, and Emmens (32) previously described (2); normal values in our laboratory are 6 to $12 \mathrm{mgm}$. per day for women and 8 to 14 mgm. per day for men.

Creatine tolerance tests were performed as follows: patients were given a creatine-creatinine-free menu for four successive days. Urinary creatine excretion on the second day was taken as the control value. On the third day $1.32 \mathrm{gm}$. of creatine hydrate powder in capsules was given. Calculation of creatine tolerance, or percentage of fed creatine retained, was based on the total excretion of creatine of the day of and the day following administration of the test dose, from which twoday total a figure was subtracted equal to twice the control day excretion. Minimal normal value for creatine tolerance, or retention, was regarded as 70 per cent with a test dose of $1.32 \mathrm{gm}$. creatine hydrate. 


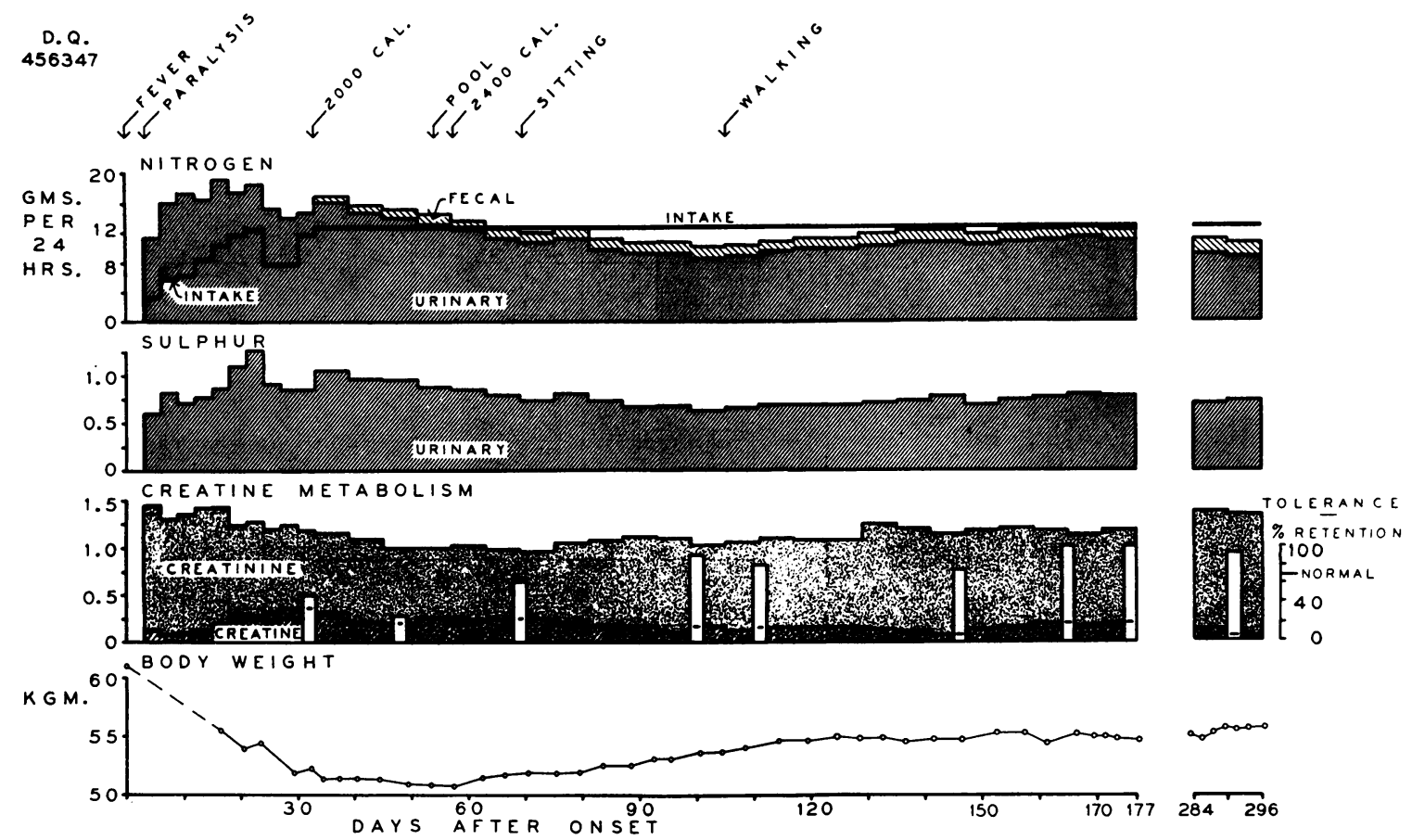

Fig. 2. Nitrogen Balance, Urinary Sulphur, Creatinine and Creatine, Creatine Tolerance and Body Weight in Patient D.Q., 21-Year-Old Male, during First Six and Tenth Months after Onset

Patient transferred to the Metabolism Ward on 14th day after onset. The balance data in this and in subsequent graphs are charted with the intake and output both plotted upward from the base-line and urinary output on the bottom in order to portray clearly changes in urinary excretion as well as changes in balance. In this and in the following graphs creatine tolerance is indicated by open bars in the creatine metabolism at the points when the tests were made.

In determination of urinary glycocyamine, arginase was prepared by the method of Hunter and Downs (33). The analytical procedure for glycocyamine was that of Hoberman (34) with substitution of the quantities of reagents used in colorimetry by Dubnoff and Borsook (35).

Serum total proteins were determined by a slight modification of the Kjeldahl method for urine (28), viz., $25 \mathrm{ml}$. of saline were added to $1 \mathrm{ml}$. of serum in the Kjeldahl flask to prevent frothing.

Girth of thighs and calves was measured at standard distances from the internal malleolus with the patient supine, generally every four to eight days. A device previously described (2) involving use of a wide metal band encircling the leg under constant and equal tension permitted measurements more accurate than those with a narrow steel measuring tape.

Muscle strength was measured in five patients every one to three weeks on an ergometer previously described (2). Muscle groups tested were the biceps, anterior tibial and gastrocnemius-soleus.

Muscle testing by Lovett technique (36) was carried out at intervals of 4 to 6 weeks by the physical therapist.

\section{RESULTS}

\section{A. Acute and early convalescent phases}

Patterns of altered metabolism can be more easily described if consideration is not limited to the acute phase (first ten days to two weeks after onset of illness) but includes the data of the first month. Description is based on the data of patients D.Q., M.O'M., D.A., and J.C. (Figures 2 to 5 ).

The clinical course of these four patients during the acute phase was usual for acute anterior poliomyelitis. None had prodromata. All four had a single-humped fever curve, lasting six to nine days, accompanied by headache, malaise, muscle tenderness, and mild gastro-intestinal symptoms. Paralysis was noted on the third, third, fourth, and second day, respectively, after the onset of fever.

1. Nitrogen. During the first two weeks after onset of illness urinary nitrogen excretion progres- 

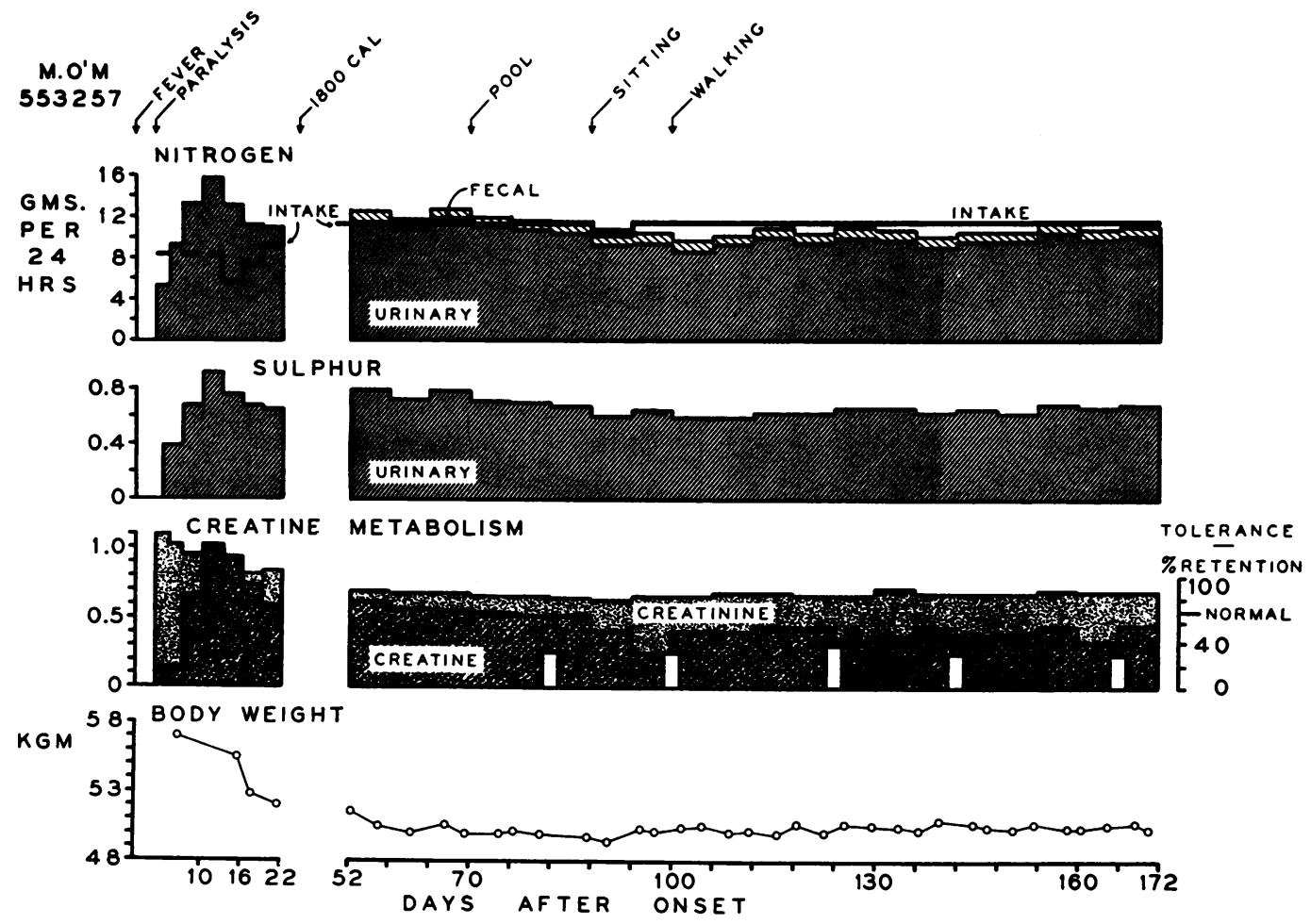

Fig. 3. Nitrogen Balance, Urinary Sulphur, Creatinine and Creatine, Creatine Tolerance and Body Weight in Patient M.O'M., 21-Year-Old Female, during First Three Weeks and Third Through Sixth Months after Onset

Patient transferred to Metabolism Ward on 13th day after onset. The interruption in this graph and those in subsequent graphs result from the exclusion of data for the periods during and for from two to four weeks following the administration of special procedures (see text).

sively increased. Maximal excretion occurred uniformly during the first half of the third week, the 16th day after onset being the mean, more than a week after fever had subsided. Late in the third week nitrogen excretion began to fall. No indication of increase in fecal nitrogen appeared during the lengthy period of marked negative nitrogen balance.

At its peak urinary nitrogen ranged from 17.5 to 29.8 grams per day among the four patients, the mean for the four being 23.4 grams per day. From stool nitrogen determinations begun shortly thereafter, nitrogen balance at the time of peak urinary nitrogen excretion may be estimated as ranging from -10.1 to -17.3 grams per day, the mean being -12.2 grams per day; this negative nitrogen balance is equivalent to a daily loss of 400 grams, or approximately one pound, of muscle protoplasm. The degree of nitrogen depletion was highly significant since at this time nitrogen intake was greater than 10 grams per day in three of the four patients. Total measured $\mathrm{N}$ loss during the first 22 days, summed from the data for only those days on which intake and output were known exactly, ranged from 89 to 185 grams among the four patients, the mean being 139.2 grams. While actual total $\mathrm{N}$ loss during the first three weeks would be somewhat more than this, the mean measured $\mathrm{N}$ loss alone during this period was equivalent to more than $41 / 2 \mathrm{Kg}$. of protoplasm.

2. Sulphur. Urinary sulphur excretion gradually increased during the first two weeks, reaching a peak which usually coincided closely in time with that of nitrogen. A noticeable lag, however, in the amounts of sulphur being excreted in relation to nitrogen, was indicated by urinary nitrogen : sulphur ratios. During the second and third weeks these ratios were more than $17: 1$ (Figure 6), definitely above the ratio of nitrogen to sulphur in muscle tissue $(37,38)$. The degree of elevation 
varied; in one patient, J.C., it was slight ; in D.Q. excessive, the ratio reaching in the second week a value of $22.7: 1$.

3. Creatine metabolism. During the first two weeks urinary creatinine excretion fluctuated more than is usually seen in well-controlled metabolism experiments; later a variable fall reflected loss of muscle mass. Creatinine index (urinary creatinine per $24 \mathrm{hrs}$./body weight on day of determination) also declined during the first month, the reduction ranging from 21 to 56 per cent and averaging 36 per cent.

Excretion of urinary creatine followed a characteristic pattern when muscle involvement was extensive. The initial urinary creatine level was generally below the normal upper limit of 0.100 to $0.125 \mathrm{gm}$. per day for male patients not on a creatine-free diet (2). At the end of the first week of illness urinary creatine increased, gradu- ally in D.Q., and rather abruptly in the three patients with greater muscle involvement. The rise ended in a peak which in three instances coincided with the peak of urinary nitrogen excretion; thereafter urinary creatine gradually declined. The maximal levels of creatinuria of patients D.A., J. C., and M.O'M. were 1.780, 1.605, and 1.080 gm. per day, respectively. In D.Q. the highest single day's excretion, $0.365 \mathrm{gm}$., coincided with the time of his maximal excretion of nitrogen, but his highest sustained elevation which was at a moderate level, occurred during the fourth week.

Only two tests of creatine tolerance were made during the first month of illness. On the 25th day, D.A. showed 52 per cent retention; on the 31 st day D.Q. showed 49 per cent retention.

Urinary glycocyamine (guanidoacetic acid), the immediate precursor of creatine, was determined at intervals during the course of these studies.

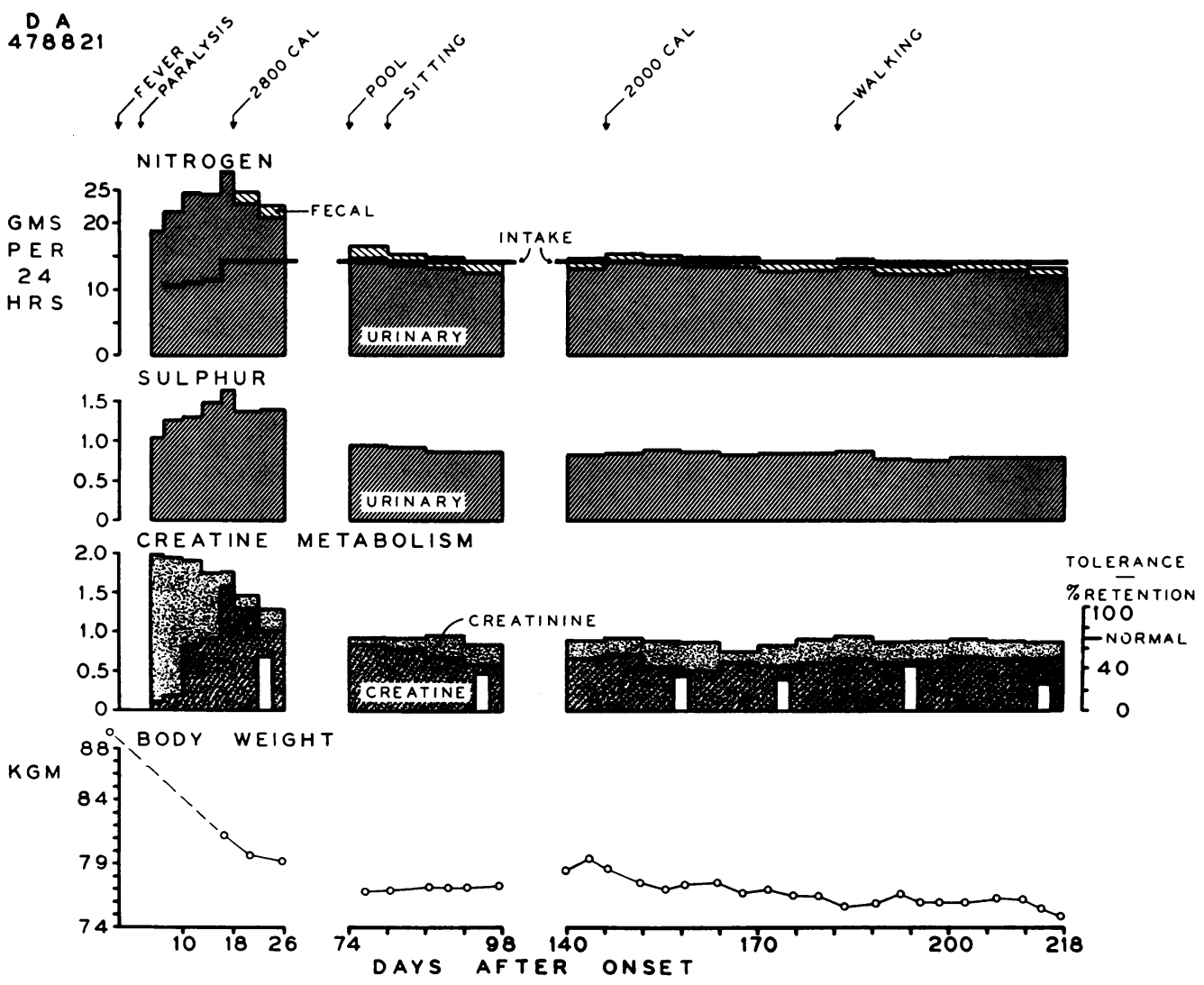

Fig. 4. Nitrogen Balance, Urinary Sulphur, Creatinine and Creatine, Creatine Tolerance and Body Weight in Patient D.A., 27-Year-Old Male, during First, Third, and Fifth Through Seventh Months after Onset

Patient transferred to Metabolism Ward on 16th day after onset. 
The few analyses revealed considerable variation but a statistically significant difference (difference between means more than 2 S. D.) in three of the four patients between excretion during the first three weeks and later levels. Mean early values and mean convalescent phase values, respectively, in mgm. per day were as follows: D.Q., 110, 80; M.O'M., 135, 89; D.A., 130, 94 ; and J.C. (difference not significant), 142, 122. None was above the normal limits of 30 to $150 \mathrm{mgm}$. per day of Sims and Seldin (39).

4. 17-Ketosteroids. Of the four patients observed during the acute phase, one, D.Q., showed a distinct fall in urinary 17 -ketosteroid excretion. His initial value on the 3rd to 5 th day after onset was $5.5 \mathrm{mgm}$. per day. From then until six weeks after onset his 17-ketosteroid excretion ranged between 1.9 and $4.9 \mathrm{mgm}$. per day; thereafter, it fluctuated between 5.3 and $7.5 \mathrm{mgm}$. per day. Patient J.C.'s initial value was $7.4 \mathrm{mgm}$. per day; one 3-day pool midway in the second week was 5.9 mgm. per day, but thereafter the values ranged between 6.5 and $9.4 \mathrm{mgm}$. per day. The 17-ketosteroid excretion of patients M.O'M. and D.A. ranged between 7.6 and 9.9 and between 8.8 and $12.2 \mathrm{mgm}$. per day, respectively, throughout their stay.

5. Body weight. During the first three weeks loss of body weight was precipitate, averaging 0.4 $\mathrm{Kg}$. per day. Caloric intake was generally variable during the first two weeks but could be considered low only during the febrile first week.

\section{B. Convalescent phase}

Definition of the duration of the convalescent phase in acute anterior poliomyelitis depends on
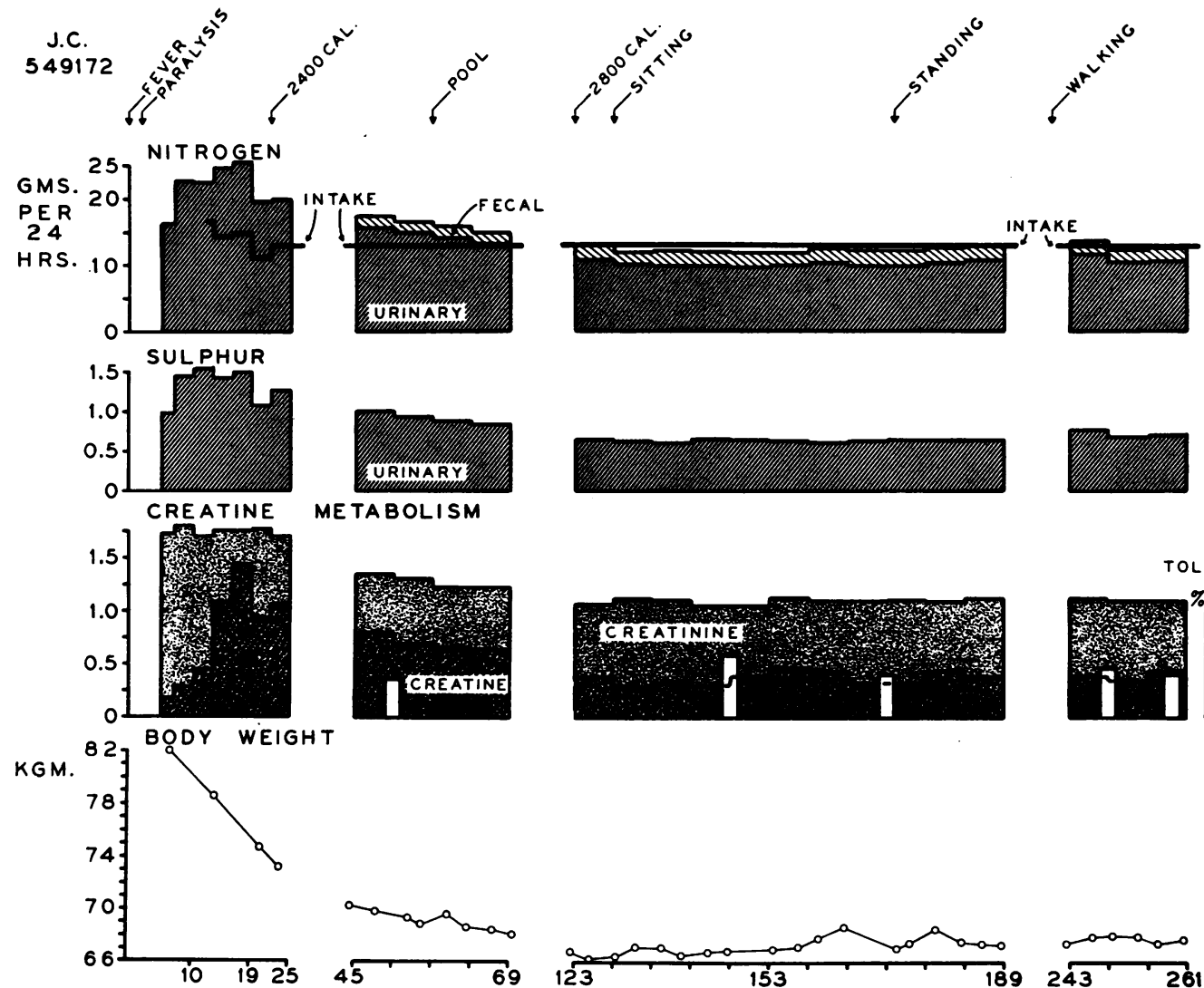

ME TABOLISM
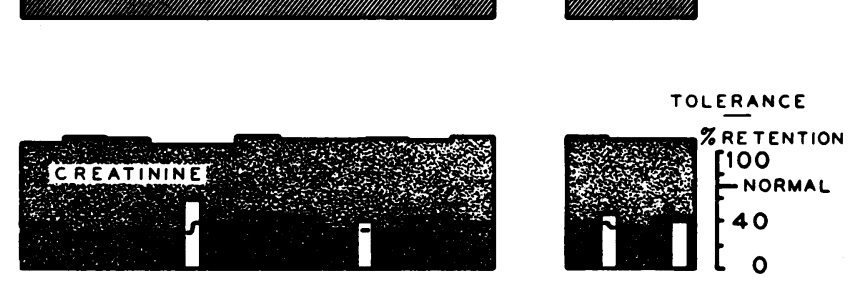

Fig. 5. Nitrogen Balance, Urinary Sulphur, Creatinine and Creatine, Creatine Tolerance and Body Weight in Patient J.C., 39-Year-Old Male, during the First, Second, Fifth, Sixth and Ninth Months AFter ONSET

Patient transferred to Metabolism Ward on 22nd day after onset. 


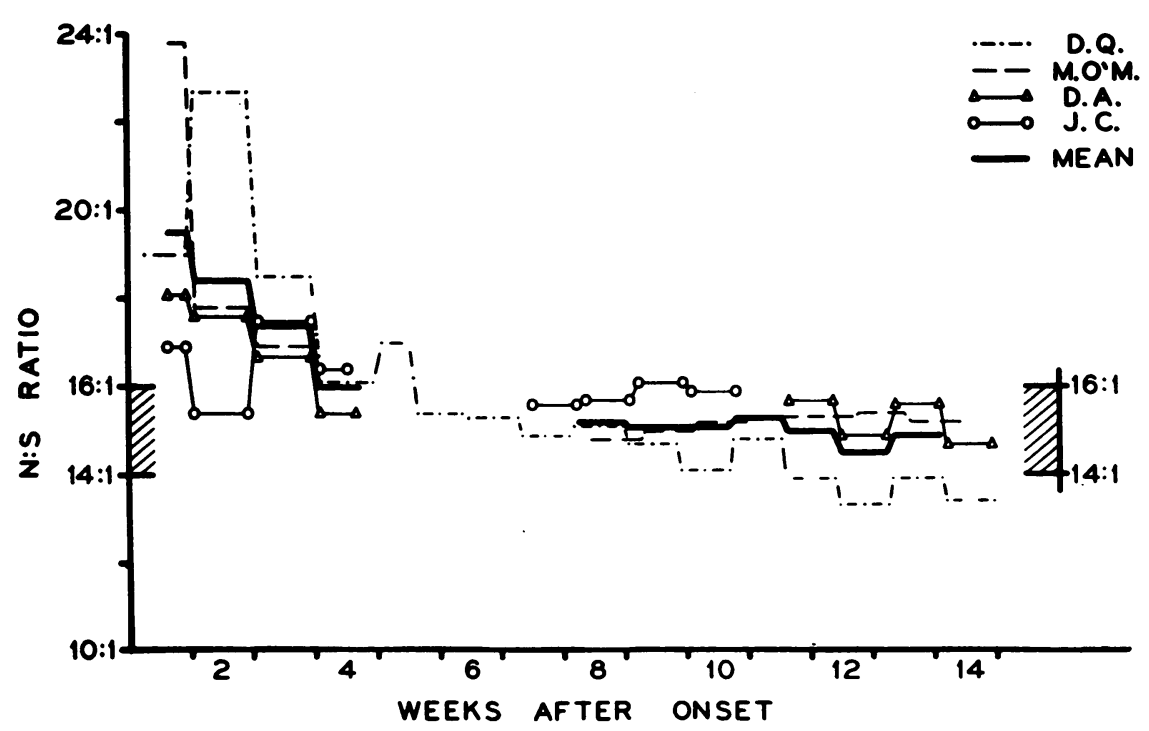

Fig. 6. Ratios of Urinary Nitrogen to Urinary Sulphur Excretion in the Four Patients Studied during the Acute as Well as Convalescent Phase

Mean ratio for the four patients is indicated by the solid black line. Normally the urinary nitrogen to sulphur ratio is between $14: 1$ and $16: 1$.

the aspect of the disease taken as criterion. Morphologic recovery of nerve cells may be complete within one month (40). Evidence of inflammatory reaction in the spinal cord is almost absent after three months (41). Recovery of muscle function has not been so specifically delimited. While clinical tests indicate that improvement may continue for 18 months to two years, most of it occurs in 6 to 10 months (42-44). Electromyographic evidence has shown that recovery in an individual muscle may continue for at least 6 months (45). The point at which metabolic processes in the tissues cease to vary has not been determined. Under these conditions, designation in Figure 1 of the duration of the convalescent phase as 6 months is arbitrary.

In this section, data obtained on 7 patients from the second through the ninth to tenth month serve as the basis for delineation of the changes in metabolism during the convalescent phase. For D.Q., M.O'M., D.A., and J.C., who were studied during the acute phase as well, parts of these data are shown in Figures 2 to 5.

1. Nitrogen. Following the peak of nitrogen excretion during the third week, noted in the first four patients, urinary nitrogen gradually decreased for several weeks. In R.W., F.S., and C.R., whose studies were begun between one and two months after onset, gradual decline in nitrogen excretion was also noted. Although studies of the latter three patients were clearly initiated after the peak, the magnitude of their nitrogen loss when first seen is worthy of note. In the fourth week after onset R.W.'s urine contained $19.5 \mathrm{gm}$. per day of nitrogen and his nitrogen balance was negative to the extent of $7.94 \mathrm{gm}$. per day; F.S. in the fifth week after onset excreted $19.8 \mathrm{gm}$. per day in the urine and had a balance of $-6.96 \mathrm{gm}$. per day.

Nitrogen balance continued to be negative for two to five months despite constant daily protein intakes of 80 to $90 \mathrm{gm}$. Mean duration of negative nitrogen balance for the 7 patients was 103 days. As might be expected, negative balance persisted longest in those with most severe muscle involvement. Patients began to sit up at approximately the time nitrogen excretion balanced nitrogen intake, and began walking approximately 5 to 6 weeks later. Hence, ambulation did not play a role in return of nitrogen equilibrium. In D.Q., who received only conventional therapy, total nitrogen loss before reestablishment of equilibrium was $308.7 \mathrm{gm}$., equivalent to a loss of $10 \mathrm{Kg}$. of muscle protoplasm; actual body weight loss for this patient over the 62 days was $9.5 \mathrm{Kg}$. Total $\mathrm{N}$ losses of M.O'M., D.A., and J.C., partially reduced in some cases by special treatments, were 165.9, 424.6 
TABLE II

Summary of data on nitrogen excretion and balance and total serum proteins, during acute and convalescent phases of paralytic acute anterior poliomyelitis

\begin{tabular}{|c|c|c|c|c|c|c|c|c|}
\hline \multirow[b]{2}{*}{ Patient } & \multicolumn{2}{|c|}{$\underset{\text { nitrogen }}{\text { Maximal urinary }}$} & \multirow{2}{*}{$\begin{array}{c}\text { Maximal } \\
\text { negative } \\
\text { balance* }\end{array}$} & \multicolumn{2}{|c|}{ Total nitrogen loss } & \multirow{2}{*}{$\begin{array}{c}\text { Time } \\
\text { to N } \\
\text { equi- } \\
\text { librium }\end{array}$} & \multicolumn{2}{|c|}{$\begin{array}{l}\text { Total serum proteins } \\
\text { first } 4 \text { months }\end{array}$} \\
\hline & Gm./day & $\begin{array}{c}\text { Day after } \\
\text { onset }\end{array}$ & & $\begin{array}{c}\text { First } \\
22 \text { days }\end{array}$ & $\begin{array}{c}\text { To N equi- } \\
\text { librium }\end{array}$ & & Mean & S.D. \\
\hline $\begin{array}{l}\text { D. Q. } \\
\text { M. O'M. } \\
\text { D. A. } \\
\text { J. C. }\end{array}$ & $\begin{array}{l}20.1 \\
17.5 \\
29.8 \\
26.4\end{array}$ & $\begin{array}{l}16 \text { th } \\
13 \text { th } \\
17 \text { th } \\
17 \text { th }\end{array}$ & $\begin{array}{r}g m . / \text { day } \\
-10.7 \\
-10.1 \\
-17.3 \\
-10.8\end{array}$ & \begin{tabular}{r}
\multicolumn{1}{c}{$g m}$. \\
173.2 \\
88.7 \\
185.2 \\
109.5
\end{tabular} & $\begin{array}{c}g m . \\
308.7 \\
165.9 \\
424.6 \\
319.5\end{array}$ & $\begin{array}{c}\text { no. of days } \\
63 \\
88 \\
93 \\
76\end{array}$ & $\begin{array}{c}g m . \% \\
6.5 \\
6.9 \\
6.8 \\
6.0\end{array}$ & $\begin{array}{l}\text { gm. \% } \\
\pm 0.21 \\
\pm 0.19 \\
\pm 0.44 \\
\pm 0.45\end{array}$ \\
\hline $\begin{array}{l}\text { Mean of } 4 \\
\text { Patients }\end{array}$ & 23.5 & 16 th & -12.2 & 139.2 & 304.7 & 80 & 6.6 & \pm 0.41 \\
\hline $\begin{array}{l}\text { R. W. } \\
\text { F. S. } \\
\text { C. R. }\end{array}$ & & & & & $\begin{array}{r}(253.1) \dagger \\
(226.9) \ddagger \\
(94.8) \S\end{array}$ & $\begin{array}{l}106 \\
147 \\
151\end{array}$ & $\begin{array}{l}6.4 \\
7.2 \\
7.0\end{array}$ & $\begin{array}{l} \pm 0.50 \\
\pm 0.27 \\
\pm 0.26\end{array}$ \\
\hline $\begin{array}{l}\text { Mean of } 7 \\
\text { Patients }\end{array}$ & & & & & & 103 & 6.7 & \pm 0.41 \\
\hline
\end{tabular}

* At time of maximal urinary nitrogen.

$\dagger$ Lacking data on nitrogen loss from onset to 19 th day.

$\ddagger$ Lacking data on nitrogen loss from onset to 30th day.

$\S$ Lacking data on nitrogen loss from onset to 49 th day.

and $317.7 \mathrm{gm}$. Mean total loss for these three patients and D.Q. was $304.7 \mathrm{gm}$., and the mean duration of their negative $\mathrm{N}$ balance was 80 days (Table II).

Return of nitrogen balance to equilibrium was usually followed by a small positive balance lasting for several weeks. This was less than $1 \mathrm{gm}$. per day except in the least involved patient, D.Q., whose balance at the time he began to walk was $+2.5 \mathrm{gm}$. per day. As he became more active, his nitrogen balance levelled off at $+0.5 \mathrm{gm}$. per day. The large early nitrogen loss was never quantitatively restored in any of the patients during the period of study.

Nitrogen to sulphur ratios in the urine after the first month were consistently within the range of $14: 1$ to $16: 1$.

2. Creatine metabolism. Fall in urinary creatinine excretion continued for from two and one-half to four months, the mean for the group of seven patients being three and one-half months. Extent of the decline was proportional to the degree of muscle involvement. For example, in D.Q. with the least muscle involvement, reduction in urinary creatinine was 31 per cent (in creatinine index, 21 per cent) over a period of two and one-half months. The creatinine of D.A., with the greatest involvement of the four acute cases studied, de- clined 58 per cent (decline in creatinine index, 51 per cent) over a three and one-half-month period (Table III). Following the phase of gradual decline, urinary creatinine remained virtually level (less than $0.08 \mathrm{gm}$. increase) except in two patients who showed a greater degree of muscle recovery than the others. In R.W. rise in urinary creatinine was slight, $0.16 \mathrm{gm}$. or approximately 12 per cent over a 4-month period; in D.Q., 10 months after onset, creatinine excretion had returned to 95 per cent of its initial level.

Day to day variation in urinary creatinine was in most patients less than $\pm 0.060 \mathrm{gm}$. In three more severely involved patients, however, values were consistently higher on the days when meat was given in the diet than on the days when the menu was creatine-creatinine-free; when beef was the principal protein source, urinary creatinine in these three patients ranged as much as 0.150 to $0.200 \mathrm{gm}$. per day higher than the values of days with creatine-creatinine-free menus.

Urinary creatine excretion, as has been stated, was extremely high during the third week in three of the four patients whose studies were begun during the acute phase. Patients R.W., F. S., and C.R., whose studies began later, had 24-hour urinary levels of $1.320,0.980$, and $0.880 \mathrm{gm}$. per day, respectively, when first seen. From these early 
TABLE III

Summary of data on creatine and creatinine excretion, changes in body weight and time of fall in leg girth, during acute and convalescent phases of paralytic acute anterior poliomyelitis

\begin{tabular}{|c|c|c|c|c|c|c|c|c|c|c|}
\hline \multirow[b]{3}{*}{ Patient } & \multirow{2}{*}{\multicolumn{2}{|c|}{$\begin{array}{l}\text { Maximal urinary } \\
\text { creatine }\end{array}$}} & \multirow{3}{*}{$\begin{array}{c}\text { Average } \\
\text { urinary } \\
\text { creatine } \\
\text { convalescent } \\
\text { phase* }\end{array}$} & \multirow{2}{*}{\multicolumn{3}{|c|}{$\begin{array}{c}\text { Fall in urinary } \\
\text { creatinine }\end{array}$}} & \multicolumn{3}{|c|}{ Weight loss } & \multirow{3}{*}{$\begin{array}{l}\text { Time of } \\
\text { fall in } \\
\text { leg girth }\end{array}$} \\
\hline & & & & & & & \multirow[b]{2}{*}{$\begin{array}{c}\text { First } \\
22 \text { days }\end{array}$} & \multicolumn{2}{|c|}{ Total loss } & \\
\hline & Gm./day & $\begin{array}{c}\text { Day after } \\
\text { onset }\end{array}$ & & Gm./day & $\begin{array}{c}\% \text { of } \\
\text { initial }\end{array}$ & $\begin{array}{l}\text { Time in } \\
\text { weeks }\end{array}$ & & Amt. & $\begin{array}{l}\text { Time in } \\
\text { weeks }\end{array}$ & \\
\hline $\begin{array}{l}\text { D. Q. } \\
\text { M. O'M. } \\
\text { D. A. } \\
\text { J. C. }\end{array}$ & $\begin{array}{l}0.365 \\
1.080 \\
1.780 \\
1.605\end{array}$ & $\begin{array}{l}17 \text { th } \\
11 \text { th } \\
17 \text { th } \\
17 \text { th }\end{array}$ & $\begin{array}{c}g m . / d a y \\
0.182 \\
0.439 \\
0.642 \\
0.458\end{array}$ & $\begin{array}{l}0.45 \\
0.47 \\
1.20 \\
0.75\end{array}$ & $\begin{array}{l}31 \\
43 \\
58 \\
42\end{array}$ & $\begin{array}{l}11 \\
13 \\
14 \\
18\end{array}$ & $\begin{array}{r}K g . \\
6.5 \\
5.0 \\
10.0 \\
8.7\end{array}$ & $\begin{array}{r}K g . \\
10.3 \\
7.3 \\
12.5 \\
15.6\end{array}$ & $\begin{array}{r}8 \\
13 \\
11 \\
18\end{array}$ & $\begin{array}{c}\text { weeks } \\
9 \\
13 \\
10 \\
17\end{array}$ \\
\hline $\begin{array}{l}\text { Mean of } 4 \\
\text { Patients }\end{array}$ & 1.208 & 16 th & 0.430 & 0.72 & 44 & 14 & 7.6 & 11.6 & 12 & 12 \\
\hline $\begin{array}{l}\text { R. W. } \\
\text { F.S. } \\
\text { C. R. }\end{array}$ & & & $\begin{array}{l}0.524 \\
0.759 \\
0.762\end{array}$ & & & $\begin{array}{l}15 \\
17 \\
17\end{array}$ & & & $\begin{array}{r}13 \\
8 \\
11\end{array}$ & $\begin{array}{l}11 \\
21 \dagger \\
11\end{array}$ \\
\hline $\begin{array}{l}\text { Mean of } 7 \\
\text { Patients }\end{array}$ & & & 0.538 & & & 15 & & & 12 & 13 \\
\hline
\end{tabular}

* Second through sixth months.

$\dagger$ Time of fall in calf girth 21 weeks, of thigh girth 7 weeks.

high levels urinary creatine gradually declined until a plateau was reached, usually at the time when creatinine excretion stopped decreasing. This new level of urinary creatine ranged from 0.150 to $0.700 \mathrm{gm}$. per day among the group of seven patients, the mean being approximately $0.440 \mathrm{gm}$. per day. In several instances there then followed a very gradual shift to a level approximately 0.100 gm. per day above the previous low. Beginning of increased activity, such as sitting and particularly actual ambulation, was attended by a distinct rise in urinary creatine, brief in those patients in whom ambulation could be carried forward progressively, small but sustained in those in whom ambulation had to be very gradual. In a few instances in which there was a rather abrupt beginning of weight-bearing on the legs, the rise in urinary creatine was accompanied by a brief (a few days) but well-marked increase in urinary phosphorus.

In D.Q. and R.W., who in later months were able to walk actively, a gradual fall in urinary creatine occurred. In R.W., however, despite a downward trend to levels as low as $0.223 \mathrm{gm}$. per day, creatinuria remained variable, ranging between 0.350 and $0.600 \mathrm{gm}$. per day at discharge nine months after onset. D.Q. had levels of 0.130 to $0.180 \mathrm{gm}$. per day upon discharge from the hospital six months after onset; upon re-entry for a two weeks' observation after a three and onehalf months' interval of active ambulation and exercise, his creatine was at normal levels of 0.120 and $0.049 \mathrm{gm}$. per day for two 6-day metabolic periods (in which the diet was not creatine-free). D.Q. was the only patient whose urinary creatine returned to normal levels. He was also the only patient whose creatine tolerance returned to normal range; this occurred a little over three months after onset of illness and prior to the beginning of ambulation. In all of the other patients, despite gradually improving muscle function, creatine tolerance tests consistently showed less than 60 per cent retention.

3. Serum proteins. Serum total proteins tended to decline slightly and very gradually in six of the seven patients, the fall averaging $0.6 \mathrm{gm}$. per cent at 4 months and $0.8 \mathrm{gm}$. per cent by 6 to 7 months. Serum proteins fell below $6.0 \mathrm{gm}$. per cent in only two patients; in R.W., three of six values during the 7 th to 9 th months were below $6.0 \mathrm{gm}$. per cent; in J.C., mean serum protein from the 2 nd through the 6 th month was $5.8 \pm 0.2 \mathrm{gm}$. per cent S.D., in contrast to the mean of $6.5 \mathrm{gm}$. per cent for three values during the first six weeks. Withdrawal from all patients of 35 to $40 \mathrm{ml}$. of blood every two to three weeks for chemistry determinations may have had some influence on the gradual fall in serum proteins. 
D. Q.

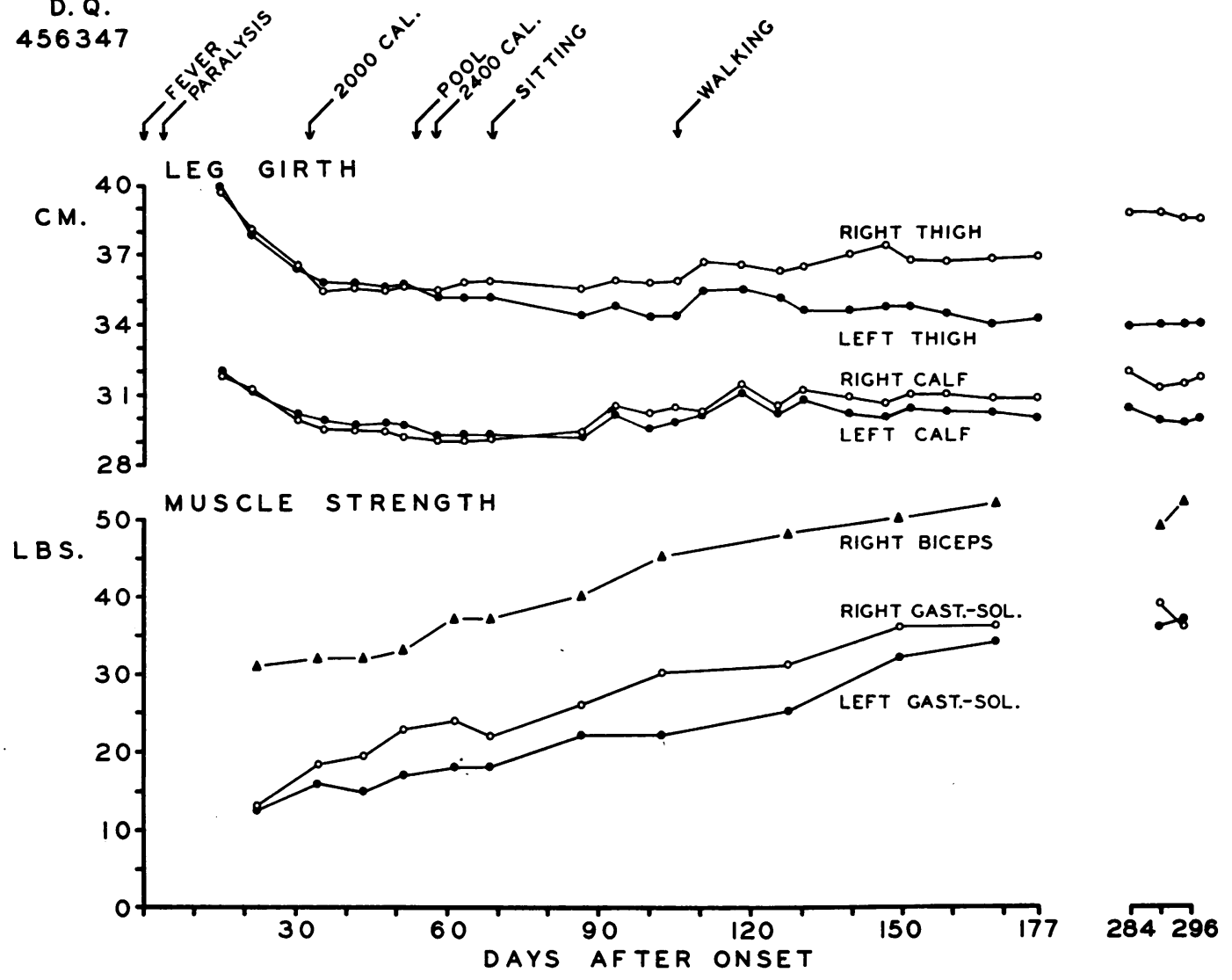

Fig. 7. Measurements of Thigh and Calf Girth and of Muscle Strength by Ergometer in the Right Biceps and Right and Left Gastrocnemius-Soleus Muscles in Patient D.Q. during the First Six and Tenth Months after Onset

In D.A. and J.C., the most severely involved of the patients studied during the acute phase, Howe fractionation of serum proteins during the first two weeks of illness revealed no abnormalities.

4. Body weight. Loss in body weight, rapid during the first three weeks, continued at a slower rate for from two to four months after onset. Mean duration of decline in weight for the seven patients was 81 days. For the four whose weights were obtained early in their illness the total weight loss ranged from 7.7 to $15.6 \mathrm{Kg}$. During this period, except for the first week of illness, dietary intakes were calorically adequate; in later months these same diets maintained weight satisfactorily. With one exception, the period of weight loss in each patient approximately coincided with that of negative nitrogen balance. In R.W., whose loss of weight ceased before nitrogen equilibrium resulted, the diet was raised from 2000 to 2400 calories without change in protein intake three months after onset.

5. Leg girth. Measurements of girth of thighs and calves showed a rapid decrease during the first month and a continuing decrease at a slower rate for two to five months, depending upon extent of muscle involvement, the average duration of decrease being twelve weeks. Leg muscle atrophy, indicated by the decline in these measurements, corresponded in time to decrease in body weight. Duration of negative nitrogen balance and of decline in urinary creatinine averaged approximately three weeks longer.

Initial measurements were not taken early enough to permit calculation of the percentile decrease in leg circumference. Indication of its extent may be obtained from a graph of the leg measurements in D.Q. (Figure 7) whose degree of decrease in girth was representative of the group. 
Following the period of decrease, leg girth tended to remain constant if involvement was severe, or gradually increased from 2 to $4 \mathrm{~cm}$. if well-marked functional improvement occurred.

6. Muscle strength. Periodic testing of muscle strength by the Lovett method was supplemented in five patients by ergometer tests of the strength of the biceps, anterior tibial and gastrocnemiussoleus muscles. In three patients ergometer tests were begun during the third week after onset of illness.

In those muscles which improved most, progressive increase in muscle power was evident within the first month, as early as a second set of tests had been made. Hence, improvement in muscle strength was evident during the time when nitrogen balance was still markedly negative, and decreasing leg girth and falling urinary creatinine indicated progressive muscle wasting.

In all these patients with moderately severe involvement, graphs of improvement in muscle power with time were not parabolic but virtually straightline. In two patients a slight acceleration in the rate of improvement possibly occurred after the beginning of standing and walking, but minor variations in the improvement of others could not be similarly explained.

Duration of improvement in muscle power was variable. Improvement continued for 5 months in D.Q. (Figure 7), and in D.A. for approximately 7 months. In the other three patients improvement had not slackened when observation was discontinued at 9 to 10 months after onset.

\section{Chronic phase}

The chronic phase of acute anterior poliomyelitis is regarded as that period in which no further significant improvement in muscle function occurs. Metabolic data relative to this phase are afforded mainly by two patients, J.W., observed from the 7 th to the 12 th month, and R.V.K., observed from the 17 th to the 24 th month (Figure 8). Most of the data indicate a relatively stable state of metabolism during these later months.

1. Nitrogen. In both patients nitrogen balance was slightly positive, averaging approximately +1 gm. daily. Nitrogen balance in the other patients (in preceding section of paper) observed after the sixth month was also slightly positive but generally less than +1 gm. daily.

Urinary nitrogen: sulphur ratios for R.V.K. and J.W. averaged 15.1:1 and 16.6:1, respectively, the latter ratio being distinctly higher than that of other patients during the convalescent and chronic phases. When these two patients were permitted to sit in a wheelchair for longer periods and to stand with crutches and long leg braces during the last three weeks of their study, both showed elevated urinary $\mathrm{N}: \mathrm{S}$ ratios, $17.3: 1$ for R.V.K. and 18.3:1 for J.W. Similar findings were noted on two occasions in other patients on beginning mobilization.

2. Creatine metabolism. In R.V.K., urinary creatinine averaging $0.20 \mathrm{gm}$. daily and a creatinine index of 7.3 were indicative of previous extreme loss of muscle tissue. From the creatinine figure, which persisted steadily throughout her stay, and from assumption that her pre-illness urinary creatinine had been 0.8 to $1.0 \mathrm{gm}$. per day (from her pre-illness weight and the average creatinine index of women), it could be estimated that this patient had lost 75 to 80 per cent of her original muscle mass. In J.W., urinary creatinine remained $0.49 \mathrm{gm}$. per day during her first ten weeks under observation, but during the last three weeks while she was being mobilized, her creatinine averaged $0.55 \mathrm{gm}$. per day.

Creatinuria remained consistently 0.500 to 0.600 gm. daily in J.W. and ranged between 0.500 and 0.750 gm. per day in R.V.K. Creatine tolerance tests averaged 35 per cent retention in J.W. and 23 per cent in R.V.K.

Several follow-up observations were made of the urinary creatine and creatinine and creatine tolerance in the four patients who had been studied during the acute phase. A single observation in D.Q., 22 months after onset of illness and a year after he had resumed his studies in medical school, showed a slightly lower urinary creatinine (fall from 1.34 to $1.25 \mathrm{gm}$. per day), a return of significant creatinuria $(0.220 \mathrm{gm}$. per day) but a continuing normal tolerance (96 per cent). A series of six observations from the 19th to the 43rd month after onset on M.O'M., who during this time was working as a secretary, showed a gradual rise in urinary creatinine from 0.68 to $0.82 \mathrm{gm}$. per day, a slight fall in creatine (to approximately 


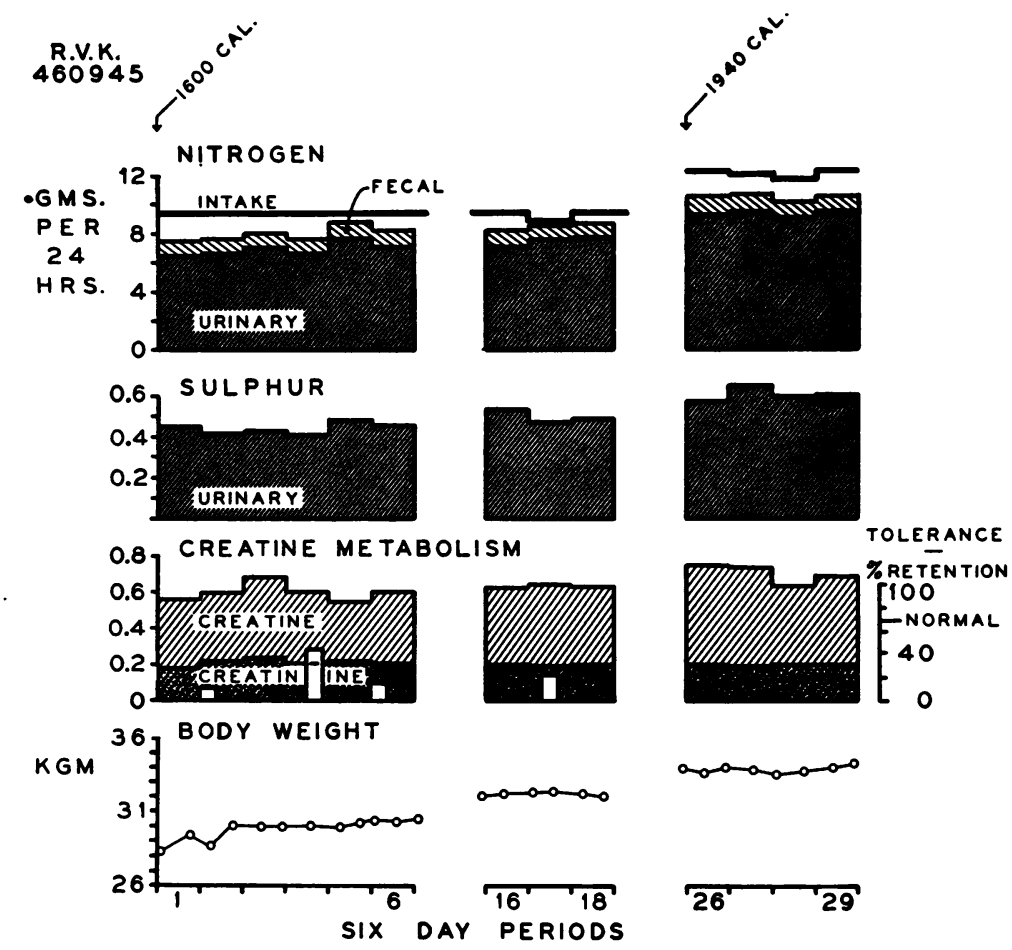

Fig. 8. Nitrogen Balance, Urinary Sulphur, Creatinine and Creatine, Creatine Tolerance and Body Weight in Patient R.V.K., 19-YearOld Female, during the 18th, 21st and 23rd Months after Onset

As indicated, urinary creatine in this patient exceeded urinary creatinine.

$0.200 \mathrm{gm}$. per day) but no significant change in her impaired creatine tolerance (33 to 67 per cent). A single observation in D.A. 34 months after onset, following continued efforts on the part of the patient to improve his muscle function, showed a slight rise in urinary creatinine from 0.90 to $0.96 \mathrm{gm}$. per day but no significant change in urinary creatine or in creatine tolerance. J.C., whose muscle involvement was extreme but limited to his legs, returned to work as an art director using a wheelchair; a series of three observations at 10,18 and 28 months after onset revealed no changes in the three indices.

3. Body weight. The body weight of J.W. remained remarkably constant during the five months she was studied. R.V.K., who weighed $28.3 \mathrm{Kg}$. (62 lbs.) when first admitted, gradually gained weight to $34.4 \mathrm{Kg}$. (76 lbs.) by the 29 th metabolic balance period.

4. Leg girth. Thigh and calf circumference of J.W. did not change appreciably during her stay. In R.V.K., who slowly gained weight and contin- ued in positive nitrogen balance, measurements showed a gradual increase of $1.1 \mathrm{~cm}$. in calf circumference and $3.5 \mathrm{~cm}$. in thigh circumference over a 6-month period.

5. Muscle strength. Ergometer tests and muscle testing by the Lovett technique revealed no significant change in muscle power in J.W. or R.V.K.

\section{COMMENT}

Data from this study make it possible to describe the pattern of a number of changes in metabolism resulting from acute anterior poliomyelitis. This pattern is well outlined for the first nine months after onset of the disease but less completely documented for the period from the 9th to the 24th month.

\section{Degree of nitrogen loss}

The most striking feature was the extraordinarily large and prolonged loss of nitrogen. Total nitrogen loss was greater (mean, $305 \mathrm{gm}$.), lasted longer (mean, 80 days) and the peak of nitrogen 
loss occurred later (mean, 16th day) than has been recorded in a number of other conditions known to provoke protein loss, such as other infectious diseases (46-52), fractures and surgical procedures (53-62). In 10 cases of meningitis observed by Grossman, Sappington, Burrows, Lavietes, and Peters (47), total nitrogen loss ranged from 3 to $180 \mathrm{gm}$. and averaged $65 \mathrm{gm}$.; negative balance lasted for an average of 9.6 days. In 14 cases of pneumonia studied by Wolf and Lambert (52) the average peak single day urinary nitrogen excretion was approximately the same (23.9 gm.) as in the group of poliomyelitis patients, but this occurred at the sixth day and negative balance was estimated to have lasted for an average of only 10 days. In a group of cases of fracture studied by Howard (58) average total loss of nitrogen was $225 \mathrm{gm}$., negative nitrogen balance lasted for 35 days and maximum excretion was reached, on an average, 6.6 days after injury.

The large nitrogen loss in paralytic poliomyelitis was ultimately succeeded by a phase of positive balance lasting several weeks. Except in the case of the least involved patient, D.Q., however, this was less than 1 gram daily. The nitrogen loss was never quantitatively restored during the period of study in any of the patients, and, in view of the irreversible character of much of the muscle damage, it is likely that in most of them the nitrogen deficit was permanent.

\section{Origin of nitrogen loss}

To account for such an extensive nitrogen deficit in poliomyelitis, several possible mechanisms must be considered. These include diminished caloric or protein intake, fever, "stress," immobilization, and atrophy of muscle tissue resulting from denervation.

When diet is rigidly restricted, gradual utilization of protein stores for energy results in a negative nitrogen balance that may be as great as 10 gm. daily in a previously healthy man (63). This deficit is readily abolished when adequate food is provided, as was shown in normal subjects in an experiment which simulated sudden withdrawal and gradual replacement of food intake generally occurring after surgery or in an infectious disease. Our patients with poliomyelitis had insufficient caloric and protein intakes for only the first week to 10 days after onset so that the influence of in- adequate intake per se on the nitrogen balance was of brief duration. Food intake had returned to a satisfactory level long before nitrogen loss had become maximal.

"Toxic" destruction of protein in febrile diseases occurs promptly (64) and, if fever is prolonged, may result in losses that are extensive (47) and difficult to overcome with high caloric feeding (48, 65 ). In patients with brief and uncomplicated fever, nitrogen loss was limited closely to the period of temperature elevation (64). In the four patients whom we studied during the acute phase, fever was not marked (mean high, $38.5^{\circ}$ ) and had subsided six to nine days after onset, well before nitrogen excretion had approached its maximal level.

A stress or insult unaccompanied by fever, such as a fracture or surgical procedure, is generally followed by excessive excretion of nitrogen (5362). In such conditions increased urinary and blood levels of 17-hydroxycorticoids have been shown to occur $(66,67)$. These events have been presumed to be related, with the possibility that nitrogen loss is either caused or permitted by increased secretion of adrenal cortical steroid (67). Paralyzing acute anterior poliomyelitis may involve similar mechanisms of nitrogen loss, but there are regrettably few data currently available which would indicate in poliomyelitis altered secretion of adrenal cortical hormones. Coriell, Siegel, Cook, Murphy, and Stokes (68) have reported low levels of circulating eosinophiles on the third day after onset. In the same series six of eight children had depressed urinary 17-ketosteroid excretion. In our complete group of eleven patients three showed a distinct fall in 17-ketosteroids. These findings contribute little and may merely be in line with previous observations that urinary total 17 -ketosteroids in stress are variable, tending to decrease if any change occurs (69). We are not aware of any determination of blood or urinary 17 -hydroxycorticoids in patients with poliomyelitis. ${ }^{3}$

\footnotetext{
${ }^{3}$ Since completion of manuscript, the report of Gemzell (91) has been noted which states that the average daily plasma 17 -hydroxycorticoid level in 15 patients with poliomyelitis during the first two weeks did not differ significantly from the levels of normal individuals in the same age range. (Footnote received after manuscript sent to press.)
} 
Although nitrogen excretion in most stress situations (70) simulates the pattern of poliomyelitis seen here, the negative nitrogen balance is of lesser magnitude, the peak loss occurs typically within the first week after trauma, and there is usually a return to nitrogen equilibrium by the third or fourth week. From these considerations it seems probable that processes currently regarded as involved in response to "stress" were operative chiefly only during the first phase of increased nitrogen loss. They fail to provide adequate explanation for the long-continuing negative nitrogen balance.

The study of immobilization on normal healthy young men has made it possible to estimate its relative importance in the excessive nitrogen excretion in poliomyelitis. The normal subjects who were immobilized by means of body plaster casts to a degree approaching that of the patients with paralytic poliomyelitis lost in six to seven weeks a total of 30 to $84 \mathrm{gm}$. of nitrogen, the mean for the group being $53.7 \mathrm{gm}$. Although a small peak in nitrogen excretion occurred at 10 days, loss was steady throughout the bed rest period. Hence, immobilization per se could be an appreciable factor, but would not account for more than 25 to 30 per cent of the total protein loss in these poliomyelitis patients.

The major source of nitrogen loss, at least after the third week, was presumably protoplasm of muscles whose nerve supply had been affected by the poliomyelitis infection. This inference is supported by the progressive decline in urinary creatinine, by correlation between the degree of decline of this constituent and proportional weight loss and by correlation of actual and theoretical weight losses, the latter calculated from nitrogen balance data.

Decline in urinary creatinine affords a measure of the degree of muscle deterioration and of the length of time during which atrophy occurred. The basis for this statement is that since 98 per cent of the creatine in the body is in muscle, 98 per cent of urinary creatinine may be assumed to reflect the daily conversion of muscle creatine to creatinine; reservation probably should be included that the unknown turnover rate of the remaining 2 per cent might introduce a small error. After initial fluctuations, urinary creatinine excretion rapidly and steadily declined for an aver- age of three and one-half months, then reached a relatively stable plateau for the remainder of the period of observation. The magnitude of the reductions in creatinine excretion and the absolute levels reached were in good correlation with clinical estimates of the extent of muscle involvement based largely on functional criteria.

The magnitude of the reductions in urinary creatinine excretion may also be compared with the loss in body weight from onset of illness until the weight became stable approximately three months later. If it is assumed that on the average the fat and carbohydrate stores of the body in the steady convalescent state ultimately became equal to those in the previously healthy state, actual weight loss would represent decrease in weight of muscle tissue. Percentage decrease in muscle tissue may then be calculated by dividing actual weight loss by the muscle mass at onset. The latter figure can be estimated from the initial body weight using the figure 40 per cent, thought to be the proportion of body weight normally represented by muscle (71). From calculations on this basis, the average decrease in muscle tissue for the four patients studied from onset was 40 per cent $(11.6 / 28.9 \mathrm{Kg}$.). For comparison, over the same period of time the average reduction in urinary creatinine excretion was 44 per cent.

Additional calculations suggesting muscle atrophy as the major source of nitrogen loss after the third week are afforded by the correlation of actual weight loss with theoretical weight loss determined from nitrogen balance data, based on a number of assumptions suggested by Reifenstein, Albright, and Wells (26). Applying the conversion factor of $1: 32$ for the weight relation of nitrogen to muscle protoplasm, theoretical weight loss was found to exceed actual weight loss by an average of 13 per cent. Applying the correction for "caloric discrepancy," which assumes that lost nitrogen represents protein made available for energy and hence sparing an isocaloric quantity of fat, the difference was narrowed to approximately 5 per cent.

Another observation which may point to atrophying muscle as the principal source of lost nitrogen was the uniform association, after the third week, of urinary nitrogen and sulphur in the proportion in which these elements occur in muscle tissue, namely, between $14: 1$ and 16:1. These 
values for muscle $N: S$, however, are based on analyses of muscles in animals and in a very few humans $(37,38)$, so that this inference must be limited by the reservation that not enough is known of the nitrogen: sulphur ratios in other tissues of the body to conclude that the ratio $14: 1-16: 1$ is distinctive only of muscle.

\section{Elevation of urinary $N: S$ ratio during early phase}

Consistent elevation of the urinary $\mathrm{N}: \mathrm{S}$ ratio during the first two to three weeks of illness suggests that, whatever tissue their source, proteins relatively poor in sulphur were being metabolized. This observation revives old concepts $(72,73)$ that there may be several types of proteins varying in availability to metabolic processes. These concepts were apparently supported by experiments in which dietary protein levels had been altered and by studies on prolonged fasts (74-76). The convincing demonstration of Schoenheimer and his associates that protein moieties are in a dynamic state has thrown doubt on the existence of separate categories of proteins in the living organism. More recently, however, this same group has obtained data which indicate that the proteins of the plasma, liver and heart turn over more rapidly than do those of muscle (77). From subsequent evaluation of these data Rittenberg (78) suggested that only a small ( 7 per cent) fraction of muscle protein is metabolically active and that the great mass of muscle is "quite inert, being a mere framework to which are attached certain active proteins."

Determinations of urinary sulphur during infectious diseases and following trauma have been made only sporadically. In the study of typhoid fever by Shaffer and Coleman (48) and in the measurements by Cuthbertson (79) following fractures or orthopedic operations the excretory ratio of $\mathrm{N}$ and $\mathrm{S}$ was not abnormal. Only in Wolf and Lambert's study (52) of pneumonia in 1910 was a tentative suggestion offered concerning preferential retention of proteins containing higher than usual amounts of sulphur; this impression was gained from the elevation of urinary $\mathrm{N}: \mathrm{S}$ ratio above 16:1 for an average of only three days in six of the fourteen patients. In the present study elevation of the ratio was noted for most of the first two to three weeks. It is of additional interest that high ratios also occurred in a few instances during the late convalescent and chronic phases when standing or sitting was instituted in four severely involved patients.

As we have stated, there is insufficient information in the literature to ascribe the $\mathrm{N}: \mathrm{S}$ excretion ratio with certainty to muscle fiber composition, and the possibility cannot be excluded that variations in renal handling of large quantities of nitrogen and sulphur may be at least partially responsible. Regardless of the explanation, however, except for the brief suggestion of this phenomenon in the pneumonia study, we are not aware that disproportion between nitrogen and sulphur excretion has been previously documented in infectious diseases or following trauma. It is puzzling that a high $\mathrm{N}: \mathrm{S}$ ratio should occur during certain stages of paralytic poliomyelitis, a disease specifically involving changes in muscle mass; whereas in infectious diseases and trauma in which a more general tissue breakdown may be present, increased nitrogen excretion is almost exclusively accompanied by the normal nitrogen: sulphur ratios found in muscle tissue.

\section{Origin of initial maximal creatinuria}

During the early weeks of the disease, in three of four patients creatinuria reached levels which were considerably higher than previously reported in paralytic poliomyelitis. From consideration of current concepts $(80,81)$ of the various possible origins of creatinuria, the principal possibilities suggested which might explain the initial peak creatinuria were as follows: increased formation of creatine, alterations in the renal mechanism for excretion of creatine, release of creatine from preformed stores in the affected muscle tissue, and a diminished capacity of the damaged muscle to incorporate the creatine presented to it. Of these various possibilities, the latter mechanism seemed most likely to be principally responsible.

Increased creatine formation during this brief phase seems unlikely from the analyses of urinary glycocyamine excretion which, although slightly greater during the first three weeks than during the convalescent phase, never exceeded normal levels. This failure of the precursor of creatine to exceed normal levels seems particularly significant with regard to creatine formation since from the work of Sims and Seldin (39) one might expect some increase in glycocyamine excretion on the basis of intereference with tubular reabsorption 
of glycocyamine by increased tubular loads of creatine.

Renal mechanisms (82) may have had a brief influence during this phase. No information is available bearing on possible variations in glomerular filtration rate during these early weeks. Depressed tubular reabsorption of creatine might occur through competition with similar substances for a common reabsorptive mechanism. Pitts (83) has concluded that excessive amounts of amino acids interfere with tubular reabsorption of creatine from experiments in dogs in which increased creatine excretion occurred as a result of infusions of glycine. Unfortunately we have no data bearing on this point since determinations of urinary amino acid nitrogen were not carried out in our patients. The possibility may be raised that a part of the creatinuria during the peak phase may have been related to alterations in adrenal cortical function, suggested from the fact that creatinuria has been described following trauma of various sorts $(79,84-86)$ and following the administration of ACTH and cortisone (87). Whether this influence occurs principally through direct muscle or renal mechanisms has not been determined; Zierler, Folk, Magladery, and Lilienthal (82) have shown diminution in tubular reabsorption of creatine on treatment with desoxycorticosterone acetate and in Cushing's disease. The meagre evidences for altered adrenal cortical function in poliomyelitis mentioned previously suggest that such changes occurred earlier in the disease than the period of peak creatinuria in these patients.

Although release or "leakage" of creatine from preformed stores in the affected muscle masses cannot be excluded, quantitative considerations make it seem unlikely that this phenomenon occurred to any great extent. For example, in D.A. who of the early group ultimately lost the greatest proportional amount of muscle mass, approximately 60 per cent, the largest daily excretion of urinary creatine amounted to only 2 per cent of his estimated total creatine mass. This level of creatinuria continued for only six days. During this same period creatine was being provided from formation in amounts which were greater than the amount being excreted. If considerable leakage had occurred, one might expect that at some point during the peak phase creatinuria would have ex- ceeded the initial level of creatinine which, in the normal state, is representative of the amount of creatine being provided to muscle each day. This was not noted in any of the four subjects.

The fourth possibility to account for the high levels of creatinuria is the development of a marked impairment in the ability to incorporate creatine in the considerable mass of damaged muscle. If the body musculature for only a few days were able to retain no more than 10 to 20 per cent of the creatine presented to it from endogenous and dietary sources, this could entirely account for the peak creatinuria in the three patients with the highest levels. [Much less impairment in incorporation is required to explain the lower levels in patient D.Q.] On this basis the subsequent decline in the levels of creatinuria may be explained by improvement in retention of creatine, possibly in conjunction with reduced endogenous formation; the latter process seemed indicated by calculations to be briefly described later. Numerous tests of tolerance to exogenous creatine were performed throughout the studies, the earliest during the fourth and fifth weeks after onset, just following the phase of peak creatinuria. The degree of impaired retention noted in these tests is consistent with the reasoning proposed. Impaired ability of muscle to incorporate creatine most reasonably accounts for the initial high levels of creatinuria. This mechanism is indeed the only one that has been so far demonstrated to occur in muscle disorders accompanied by creatinuria ; in progressive muscular dystrophy, isotopic studies by Benedict, Kalinsky, Scarrone, Wertheim, and Stetten (88) have established that this mechanism is responsible for the creatinuria.

For the persistent creatinuria of the convalescent and chronic phases in the patient with moderate or severe paralysis due to poliomyelitis, presumably a similar explanation holds with the following modification: by the second to third month an actual considerable reduction has developed in muscle mass available for creatine retention, while production persists at normal or reduced though abundant levels.

\section{Rates of creatine formation and conversion to creatinine}

The creatine-creatinine data were analyzed in the light of our present understanding of the: 
processes of creatine formation and conversion. It is regrettable that studies with isotopic creatine were not included; nevertheless, it was possible to utilize the data for calculations which yielded information on the conversion rates of creatine to creatinine and on the constancy of endogenous creatine formation. The data analyzed covered the first four to eleven weeks of the four patients studied during the acute and convalescent phases.

Space does not permit detailed presentation of the calculations but merely an indication of their basis and the results obtained. Effort was made to account quantitatively for the observed day to day decline in urinary creatinine on the basis of a gradual decrease in total body creatine stores. In any individual, total creatine stores (S) are being replenished daily by creatine provided by endogenous formation $\left(C_{f}\right)$ and are being depleted daily through two avenues of loss, conversion to creatinine $\left(C_{\text {con }}\right)$ and excretion of creatine in the urine $\left(C_{e x}\right)$. The latter figure for the calculations was supplied by the analyzed quantities of creatine in the urine. The figure for constant daily creatine formation $\left(C_{f}\right)$ was taken as the pre-illness (or initial) urinary creatinine; this is based on the observations that in health the daily excretion of creatinine is relatively constant and that there is little excretion of creatine in the urine on creatine-creatinine-free diets, leading to the inference that under normal conditions creatine stores are maintained by the endogenous formation of creatine in amounts equivalent to those degraded daily to creatinine. Day by day calculations were made and tabulated of the amounts of creatine daily converted to creatinine and of the changing total body stores of creatine, by the following formulae:

$$
\begin{aligned}
& \text { (1) } \mathrm{S}_{\text {beginning of day }}+\mathrm{C}_{f}-\mathrm{C}_{\mathrm{ex}}-\mathrm{C}_{\text {con }}=\mathrm{S}_{\text {end of day }} \\
& \text { (2) } \mathrm{C}_{\text {con }}=\mathrm{S}_{\text {beginning of day }} \mathrm{x} \text { ? } \%
\end{aligned}
$$

For each successive day's calculation $S_{\text {beginning of day }}$ was the figure obtained as $S_{\text {end of day }}$ in the preceding day's calculation. Various figures for a constant rate of conversion to creatinine were successively tried; the reasonable range within which to test was provided by the study using isotopic creatine in rats (89) in which 2 per cent of the creatine stores were found to be converted to creatinine daily and by the similar study (90) in one normal man which gave a value of 1.64 per cent. The initial total quantity of muscle creatine, with which the calculations were begun, was obtained by dividing the initial level of urinary creatinine by the percentage conversion being tested. The calculated daily values for creatine loss by conversion $\left(\mathrm{C}_{\mathrm{con}}\right)$ were compared with the declining daily analyzed values of urinary creatinine. The correspondence of these two sets of figures provided the test of validity of the various rates of conversion under trial. In certain patients at various stages, changes in creatine formation were invoked to bring about closer alignment of the analyzed and calculated values for creatinine.

The results of these calculations are presented with the realization that their reliability is limited by the assumptions required and by the relative non-specificity of the Folin method, but with the hope that they may stimulate others to investigate these processes further. In one of the four patients, M.O'M., the calculated values for creatinine declined day by day in close agreement with the analyzed values when the calculations were based on a constant conversion rate of 2.2 per cent; the analyzed and calculated data fitted well from onset through the eleventh week when a steady state was reached in which analyzed values for creatine and creatinine and calculated values for creatinine became relatively constant. In the other three patients the analyzed creatinine values agreed moderately well with calculated values during the first two to four weeks at conversion rates varying from 1.2 per cent to 3 per cent. Thereafter the analyzed values fell more rapidly than could be accounted for by any constant conversion rate and constant endogenous creatine formation. Although a progressive reduction in the conversion rate of creatine to creatinine might have occurred, the more reasonable possibility and the one on which agreement was possible for all three patients was the assumption of a continuing constant conversion rate and a decrease in endogenous creatine formation. The analyzed and calculated data of D.A. fitted best with a constant conversion rate of 3 per cent and a reduction in creatine formation of 50 per cent beginning at approximately the 13 th day. In J.C., the data fitted best with a constant conversion rate of 1.2 per cent and a reduction of 40 per cent in creatine formation beginning at approximately the 26 th day. And in D.Q., the data 
fitted best with a constant conversion rate of 3 per cent and a reduction of 30 per cent in creatine formation beginning at approximately the 16th day. At these rates the calculated data in all three patients remained in close agreement with the analyzed data from onset into a steady-state (for both analyzed and calculated data) beginning after the seventh week.

The indication that creatine formation was reduced in these three patients was supported by the fact that from the third month on, the sum of the daily analyzed urinary creatine and creatinine was from 16 to 28 per cent less than the values of the urinary creatinine at onset. In M.O'M, in whose calculations it was not necessary to assume a decrease in creatine formation, the sum of urinary creatine and creatinine in the convalescent phase was approximately equal to the initial values of creatinine, suggesting that in this patient endogenous creatine formation was not reduced.

\section{Muscle power}

Results of periodic tests of muscle power with an ergometer emphasized individual variation in duration of improvement. It is generally stated that most of the recovery of muscle function occurs uniformly during the first six to ten months and that with rare exception no further improvement should be anticipated after approximately the sixteenth month. In the present group significant improvement ceased at six to seven months in three patients, while in another three recovery of power continued steadily for more than nine to ten months. Late follow-up determinations of urinary creatine and creatinine in four patients revealed in one a progressive increase in urinary creatinine through the forty-third month. Data in this patient support the observation that significant improvement may occasionally occur as late as three or more years after onset of illness.

Improvement in muscle function was usually unaccompanied by parallel changes in nitrogen or creatine metabolism. During the early weeks it occurred simultaneously with a markedly negative nitrogen balance and decreasing leg girth and urinary creatinine, indicative of progressive muscle wasting. This dissociation is consistent with progressive atrophy of muscle bundles whose neurons were destroyed concurrent with return of function in bundles whose neurons had recovered; subsequent improvement in muscle strength has been related to hypertrophy of surviving muscle bundles. During the later convalescent phase, functional recovery was unaccompanied by a significant gradual rise in urinary creatinine except in two patients. Although we have emphasized the long duration of metabolic changes, particularly in contrast to other disease conditions, relative stability in nitrogen balance and creatinuria was reattained long before cessation of improvement in muscle function.

\section{Time of ambulation}

With respect to the proper time to begin ambulation, this report raises a question. Deleterious effects have been described of prolonged immobilization on protein and mineral metabolism and on certain aspects of circulation. On the other hand, the fact that in several of our conservatively managed patients increases in urinary creatine and phosphorus occurred when they began to bear weight suggests the possibility of some danger to muscle tissue from too early ambulation. This question requires further study.

\section{SUM MARY}

Metabolic studies were carried out for periods of six to nine months each on nine patients extensively paralyzed by acute anterior poliomyelitis. In four patients observations were begun during the first week of the disease and extended through the convalescent phase. Three patients were studied during the convalescent phase only and two were studied during the chronic phase. The present paper was limited to description of nitrogen and creatine-creatinine data obtained during administration of standard therapy, with the view of delineating the natural history of the disease with respect to these metabolites. Principal findings were as follows :

1. A large and prolonged loss of nitrogen reached its maximum on the average 16 days after onset of illness and lasted two to five months. Mean duration of negative nitrogen balance was 103 days. Average total nitrogen loss (negative balance) of the four patients whose studies were begun within the first week of illness was 304.7 grams (equivalent to $9 \mathrm{Kg}$. of muscle protoplasm).

2. The major portion of nitrogen loss appeared 
to be related to atrophy of muscle tissue, as judged from associated observations of fall in urinary creatinine and decreases in body weight from the third week of illness on. It was estimated that immobilization might be responsible for 25 to 30 per cent of the nitrogen loss. Nitrogen loss of the first three weeks was associated with a high urinary $\mathrm{N}: \mathrm{S}$ ratio.

3. Creatinuria, developing in the first week of illness, increased rapidly to a maximum during the third week, then declined to persistent intermediate levels averaging $0.440 \mathrm{gm}$. per day. Of several alternate explanations for the initial peak creatinuria, impaired incorporation of creatine into damaged muscle mass was considered the most likely.

4. Urinary creatinine declined for from two and one-half to four months. The degree of decline ranged from 31 to 58 per cent and was proportional to the extent and severity of muscle involvement.

5. Body weight loss was rapid during the first three weeks and continued for an average of 81 days, despite caloric intakes after the first week which would be adequate under normal circumstances. Weight loss ranged from 7.7 to $15.6 \mathrm{Kg}$. among the four patients studied from the first week of illness.

6. Muscle strength steadily improved during the phase of negative nitrogen balance and falling urinary creatinine. Results of periodic ergometer tests emphasized variation from one patient to another in the duration of improvement in muscle power. Although improvement in muscle power was generally unaccompanied by parallel changes in nitrogen or creatine excretion, in one patient a gradual increase in urinary creatinine more than three years after onset of disease indicated that significant improvement in muscle function was still occurring at that time.

7. A new, relatively steady state with respect to nitrogen balance and creatinuria was established on the average three to four months after onset. The degree and persistence of the alterations noted in this study evidenced the extent and chronicity of metabolic defects in paralytic poliomyelitis.

\section{ACKNOWLEDGMENTS}

The authors wish to acknowledge gratefully the close association of Dr. John E. Deitrick in the planning of these studies and his helpful participation during the early stages. The authors also wish to express their appreciation for the conscientious and careful assistance of the nurses of the Metabolism Ward, especially Head Nurses Alice Monroe and, later, Elizabeth Cunningham; of the dietitians of the Metabolism Ward at various stages, Dorothy Clymer, Jean Jacobson and Virginia Lewis; and of the nurses of the Infectious Disease Ward. These studies were aided immeasurably by the very close cooperation and help of the members of the Department of Physical Medicine, whose attentive work with our patients was arranged and supervised by Dr. Kristian G. Hansson and Miss Margaret Valentine. At various stages Drs. George J. Hamwi and Bernard Wissmer participated in the studies and aided them most effectively. Grateful appreciation is also due to Dr. David P. Barr for his advice and criticism in the preparation of these papers.

\section{REFERENCES}

1. Sanders, C. E., Cardiovascular and peripheral vascular diseases. Treatment by a motorized oscillating bed. J. A. M. A., 1936, 106, 916.

2. Deitrick, J. E., Whedon, G. D., and Shorr, E., Effects of immobilization upon various metabolic and physiologic functions of normal men. Am. J. Med., $1948,4,3$.

3. Levene, P. A., and Kristeller, L., Factors regulating the creatinin output in man. Am. J. Physiol., 1909, 24, 45.

4. Bürger, M., Beiträge zum Kreatininstoffwechsel. II. Die Kreatin- und Kreatininausscheidung bei Störungen des Muskelstoff wechsels. Zeitschrift f. d. ges. Exper. Med., 1919, 9, 361.

5. Cameron, A. T., and Gibson, A., Creatinuria in certain diseased conditions. Canad. M. A. J., 1922, 12, 393.

6. Gibson, R. B., Martin, F. T., and Buell, M. Van R., A metabolic study of progressive pseudohypertrophic muscular dystrophy and other muscular atrophies. Arch. Int. Med., 1922, 29, 82.

7. Magers, E. J., A study of certain phases of metabolism in poliomyelitis. J. Biol. Chem., 1934, 105, Proc. lvi.

8. Gros, W., Der Kreatin-Kreatininstoff wechsel bei spinaler Kinderlähmung und seine Beeinflussung durch Glykokoll. Zeitschrift f. klin. Med., 1934, 126, 152.

9. Kostakow, S., Uber Spontankreatinurie bei Nervenerkrankungen. D. Archiv. klin. Med., 1936, 178, 387.

10. Milhorat, A. T., and Wolff, H. G., Studies in diseases of muscle. IV. Metabolism of creatine and creatinine in muscular wasting subsequent to disease of the nervous system. Arch. Neurol. \& Psychiat., 1938, 40, 663.

11. Wang, E., Clinical and experimental investigations on the creatine metabolism. Chapter VII. Creatine and creatinine in postpoliomyelitic paralysis. Acta med. Scandinav., 1939, Suppl. 105, 176. 
12. Brфchner-Mortensen, $K$., Creatinuria in poliomyelitis. Acta med. Scandinav., 1949, Supp. 234, 93.

13. Boines, G. J., and Kakavas, J. C., Creatine excretion in acute poliomyelitis. Preliminary report. Delaware State M. J., 1950, 22, 304.

14. Gifford, R., and Dalldorf, G., Creatinine, potassium and virus content of the muscles following infection with the "Coxsackie Virus." Proc. Soc. Exper. Biol. \& Med., 1949, 71, 589.

15. Bower, A. G., Morgan, F. M., and Chaney, A. L., Nitrogen and potassium metabolism: The reaction pattern in poliomyelitis. Am. J. M. Sc., 1952, 223, 532.

16. Bower, A. G., Eaton, R. M., Chudnoff, J. S., Affeldt, J. E., and Chaney, A. L., Patterns of plasma protein changes in acute poliomyelitis patients: treatment with blood plasma. Am. J. M. Sc., 1950, 220, 46.

17. Routh, J. I., and Paul, W. D., Electrophoretic studies of plasma and serum proteins in anterior poliomyelitis. Arch. Phys. Med., 1951, 32, 397.

18. Steigman, A. J., Brodsky, W. A., and Stephens, R. N., Normal distribution of serum protein levels in acute poliomyelitis patients. J. Lab. \& Clin. Med., 1952, 39, 757.

19. Sherman, H. C., Chemistry of Food and Nutrition, 7th ed. New York, The Macmillan Company, 1946.

20. Bowes, A. DeP., and Church, C. F., Food Values of Portions Commonly Used, 6th ed. Philadelphia, Anna de P. Bowes, 1946.

21. Turner, D. F., Handbook of Diet Therapy. Chicago, Univ. of Chicago Press, 1946.

22. Mead Johnson and Co. Research Laboratory, $\mathrm{Na}$ and $\mathrm{K}$ analyses of American food stuffs; determinations by flame photometer, Third list, Evansville, Mead Johnson and Co., December, 1946.

23. Bills, C. E., McDonald, F. G., Niedermeier, W., and Schwartz, M. C., Sodium and potassium in foods and waters. Determination by the flame photometer. J. Am. Dietet. A., 1949, 25, 304.

24. DuBois, E. F., The Metabolism Ward of the Russell Sage Institute of Pathology. Methods and Problems of Medical Education, Eleventh Series, 1928, p. 49.

25. Sampson, A. G., Sprague, R. G., and Wollaeger, E. E., Dietary techniques for metabolic balance studies. J. Am. Dietet. A., 1952, 28, 912.

26. Reifenstein, E. C., Jr., Albright, F., and Wells, S. L., The accumulation, interpretation, and presentation of data pertaining to metabolic balances, notably those of calcium, phosphorus and nitrogen. J. Clin. Endocrinol., 1945, 5, 367.

27. Toscani, V., and Whedon, G. D., Nitrogen loss in the feces: The variability of excretion in normal subjects on constant dietary intakes. J. Nutrition, 1951, 45, 119.

28. Folin, O., and Wright, L. E., A simplified macroKjeldahl method for urine. J. Biol. Chem., 1919, 38, 461.
29. Hawk, P. B., and Bergeim, O., Practical Physiological Chemistry, 11th ed. Philadelphia, P. Blakiston's Son and Co., 1937, p. 758.

30. Benedict, S. R., Studies in creatine and creatinine metabolism. II. The estimation of creatine. J. Biol. Chem., 1914, 18, 191.

31. Folin, O., On the determination of creatinine and creatine in urine. J. Biol. Chem., 1914, 17, 469.

32. Callow, N. H., Callow, R. K., and Emmens, C. W., Colorimetric determination of substances containing the grouping $-\mathrm{CH}_{2} \cdot \mathrm{CO}-$ in urine extracts as an indication of androgen content. Biochem. J., 1938, 32, 1312.

33. Hunter, A., and Downs, C. E., The measurement of arginase activity. J. Biol. Chem., 1944, 155, 173.

34. Hoberman, H. D., The determination of guanidoacetic acid and arginine in human urine and serum. J. Biol. Chem., 1947, 167, 721.

35. Dubnoff, J. W., and Borsook, H., A micromethod for the determination of glycocyamine in biological fluids and tissue extracts. J. Biol. Chem., 1941, 138, 381 .

36. Lovett, R. W., The Treatment of Infantile Paralysis. Philadelphia, P. Blakiston's Son and Co., 1916.

37. Katz, J., Die mineralischen Bestandtheile des Muskelfleishes. Archiv. (Pflüger's) f.d. ges. Physiol., 1896, 63, 1.

38. Lee, F. S., Scott, E. L., and Colvin, W. P., Some of the chemical properties of certain mammalian muscles. Am. J. Physiol., 1916, 40, 474.

39. Sims, E. A. H., and Seldin, D. W., Reabsorption of creatine and guanidoacetic acid by the renal tubules. Am. J. Physiol., 1949, 157, 14.

40. Bodian, D., Poliomyelitis: Pathologic anatomy. First International Poliomyelitis Conference. Philadelphia, J. B. Lippincott Company, 1949, pp. 62-84.

41. Bell, E. T., The progressive pathology of poliomyelitis. Ibid., pp. 135-141.

42. Green, W. T., The management of poliomyelitis: The convalescent stage. Ibid., pp. 165-185.

43. Steindler, A., Poliomyelitis: The convalescent stage; discussion of Ghormley, R. K., and Allen, C. S., Progressive deformities in poliomyelitis. Ibid., $\mathbf{p}$. 152.

44. Sharrard, W. J. W., Muscle recovery in poliomyelitis. J. Bone \& Joint Surg., 1955, 37-B, 63.

45. Buchtal, F., Some aspects of the pathologic physiology of poliomyelitis. First International Poliomyelitis Conference. Philadelphia, J. B. Lippincott Company, 1949, pp. 85-95.

46. Peters, J. P., Problems of nitrogen metabolism. Federation Proc., 1944, 3, 197.

47. Grossman, C. M., Sappington, T. S., Burrows, B. A., Lavietes, P. H., and Peters, J. P., Nitrogen metabolism in acute infections. J. Clin. Invest., 1945, 24, 523.

48. Shaffer, P. A., and Coleman, W., Protein metabolism in typhoid fever. Arch. Int. Med., 1909, 4, 538. 
49. Barr, D. P., and DuBois, E. F., Clinical calorimetry. XXVIII. The metabolism in malarial fever. Arch. Int. Med., 1918, 21, 627.

50. Coleman, W., Barr, D. P., and DuBois, E. F., Clinical calorimetry. XXX. Metabolism in erysipelas. Arch. Int. Med., 1922, 29, 567.

51. Cecil, R. L., Barr, D. P., and DuBois, E. F., Clinical calorimetry. XXXI. Observations on the metabolism of arthritis. Arch. Int. Med., 1922, 29, 583.

52. Wolf, C. G. L., and Lambert, A., Protein metabolism in pneumonia. Arch. Int. Med., 1910, 5, 406.

53. Cuthbertson, D. P., The disturbance of metabolism produced by bony and non-bony injury, with notes on certain abnormal conditions of bone. Biochem. J., 1930, 24, 1244.

54. Cuthbertson, D. P., Further observations on the disturbance of metabolism caused by injury, with particular reference to the dietary requirements of fracture cases. Brit. J. Surg., 1936, 23, 505.

55. Cuthbertson, D. P., Post-shock metabolic response. Lancet, 1942, 1, 433.

56. Howard, J. E., Metabolic observations on patients convalescent from fracture. Tr. A. Am. Physicians, 1944, 58, 162.

57. Howard, J. E., Parson, W., Stein, K. E., Eisenberg, $H$, and Reidt, V., Studies on fracture convalescence. I. Nitrogen metabolism after fracture and skeletal operations in healthy males. Bull. Johns Hopkins Hosp., 1944, 75, 156.

58. Howard, J. E., Protein metabolism during convalescence after trauma. Arch. Surg., 1945, 50, 166.

59. Brunschwig, A., Clark, D. E., and Corbin, N., Postoperative nitrogen loss and studies on parenteral nitrogen nutrition by means of casein digest. Ann. Surg., 1942, 115, 1091.

60. Mulholland, J. H., Tui, Co, Wright, A. M., and Vinci, V. J., Nitrogen metabolism, caloric intake and weight loss in postoperative convalescence. Ann. Surg., 1943, 117, 512.

61. Braasch, J. W., Protein metabolic response to trauma. Internat. Abstr. Surg., 1949, 88, 473.

62. Moore, F. D., and Ball, M. R., The Metabolic Response to Surgery. Springfield, Charles C Thomas, 1952.

63. Howard, J. E., Bigham, R. S., Jr., Eisenberg, H., Wagner, D., and Bailey, E., Studies on convalescence. IV. Nitrogen and mineral balances during starvation and graduated feeding in healthy young males at bed rest. Bull. Johns Hopkins Hosp., 1946, 78, 282.

64. Howard, J. E., Bigham, R. S., Jr., and Mason, R. E., Studies on convalescence. V. Observations on the altered protein metabolism during induced malarial infections. Tr. A. Am. Physicians, 1946, 59, 242.

65. Coleman, W., and DuBois, E. F., Clinical calorimetry, seventh paper. Calorimetric observations on the metabolism of typhoid patients with and without food. Arch. Int. Med., 1915, 15, 887.
66. Moore, F. D., Steenburg, R. W., Ball, M. R., Wilson, G. M., and Myrden, J. A., Studies in surgical endocrinology. I. The urinary excretion of 17hydroxycorticoids, and associated metabolic changes, in cases of soft tissue trauma of varying severity and in bone trauma. Ann. Surg., 1955, 141, 145.

67. Steenburg, R. W., Lennihan, R., and Moore, F. D., Studies in surgical endocrinology. II. The free blood 17-hydroxycorticoids in surgical patients; their relation to urine steroids, metabolism and convalescence. Ann. Surg., 1956, 143, 180.

68. Coriell, L. L., Siegel, A. C., Cook, C. D., Murphy, L., and Stokes, J., Jr., Use of pituitary adrenocorticotrophic hormone (ACTH) in poliomyelitis. J. A. M. A., 1950, 142, 1279.

69. Forbes, A. P., Donaldson, E. C., Reifenstein, E. C., Jr., and Albright, F., The effect of trauma and disease on the urinary 17-ketosteroid excretion in man. J. Clin. Endocrinol., 1947, 7, 264.

70. Selye, H., The Physiology and Pathology of Exposure to Stress. Montreal, Acta, Inc., 1950, p. 152.

71. Shohl, A. T., Mineral Metabolism. New York, Reinhold Publishing Corp., 1939, p. 29.

72. Voit, C., Herrmann's Handbuch der Physiologie. Leipzig, 1881. Quoted by Wilson (76).

73. Rubner, M., Ueber den Eiweissansatz. Arch. Physiol., 1911, p. 68. Quoted by Wilson (76).

74. Lusk, G., The Elements of the Science of Nutrition, 4th ed. Philadelphia, W. B. Saunders Company, 1928, p. 92.

75. Wilson, H. E. C., The relation between sulphur and nitrogen metabolism. Biochem. J., 1925, 19, 322.

76. Wilson, H. E., C., Studies on the physiology of protein retention. J. Physiol., 1931, 72, 327.

77. Shemin, D., and Rittenberg, D., Some interrelationships in general nitrogen metabolism. J. Biol. Chem., 1944, 153, 401.

78. Rittenberg, D., Dynamic aspects of the metabolism of amino acids. Harvey Lectures, Series XLIV, 194849, pp. 200-219.

79. Cuthbertson, D. P., The distribution of nitrogen and sulphur in the urine during conditions of increased catabolism. Biochem. J., 1931, 25, 236.

80. Hunter, A., Creatine and Creatinine. London, Longmans, Green and Co. Ltd., 1928.

81. Beard, H. H., Creatine and Creatinine Metabolism. Brooklyn, Chemical Publishing Co., Inc., 1943.

82. Zierler, K. L., Folk, B. P., Magladery, J. W., and Lilienthal, J. L., Jr., On creatinuria in man. The roles of the renal tubule and of muscle mass. Bull. Johns Hopkins Hosp., 1949, 85, 370.

83. Pitts, R. F., A renal reabsorptive mechanism in the dog common to glycin and creatine. Am. J. Physiol., 1943, 140, 156.

84. Cuthbertson, D. P., McGirr, J. L., and Robertson, J. S. M., The effect of fracture of bone on the metabolism of the rat. Quart. J. Exper. Physiol., 1939, 29, 13. 
85. Croft, P. B., and Peters, R. A., Nitrogen loss after thermal burns; effects of adding protein and methionine to diet of rats. Lancet, 1945, 1, 266.

86. Clark, E. J., Peters, R. A., and Rossiter, R. J., Nitrogen metabolism after burning. Quart. J., Exper. Physiol., 1946, 33, 113.

87. Sprague, R. G., Power, M. H., Mason, H. L., Albert, A., Mathieson, D. R., Hench, P. S., Kendall, E. C., Slocumb, C. H., and Polley, H. F., Observations on the physiologic effects of cortisone and ACTH in man. Arch. Int. Med., 1950, 85, 199.

88. Benedict, J. D., Kalinsky, H. J., Scarrone, L. A., Wertheim, A. R., and Stetten, DeW., Jr., The ori- gin of urinary creatine in progressive muscular dystrophy. J. Clin. Invest., 1955, 34, 141.

89. Bloch, K., Schoenheimer, R., and Rittenberg, D., Rate of formation and disappearance of body creatine in normal animals. J. Biol. Chem., 1941, 138, 155.

90. Hoberman, H. D., Sims, E. A. H., and Peters, J. H., Creatine and creatinine metabolism in the normal male adult studied with the aid of isotopic nitrogen. J. Biol. Chem., 1948, 172, 45.

91. Gemzell, C. A., The poliomyelitis epidemic in Stockholm 1953. XVI. Adrenal cortical activity of patients with poliomyelitis acuta. Acta med. Scandinav., 1956, Suppl. 316, 104. 